\title{
Would you fight? \\ We asked aggrieved artisanal miners in Eastern Congo
}

\author{
NiK STOOP AND MARIJKE VERPOORTEN
}

This paper is forthcoming in The Journal of Conflict Resolution.

(https://doi.org/10.1177/0022002720983437)

Stoop: Institute of Development Policy, University of Antwerp; Centre for Institutions and Economic Performance, University of Leuven; Research Foundation Flanders (nik.stoop@uantwerp.be).

Verpoorten: Institute of Development Policy, University of Antwerp; Centre for Institutions and Economic Performance, University of Leuven (marijke.verpoorten@uantwerp.be)

\section{Funding}

This work was supported by Research Foundation Flanders [grant numbers 1517614N, 11Q2816N, and 30784531]; and the Centre d'Expertise en Gestion Minière (CEGEMI).

\section{Replication}

Data and replication files can be consulted on the Harvard Dataverse repository (https://doi.org/10.7910/DVN/IWTDSF).

\section{Acknowledgements}

Permission to conduct the research was granted by the University of Antwerp's Ethics Committee for the Social Sciences and Humanities (file nr. SHW_15_06), by the Congolese Ministry of Mines, by SAESSCAM and by local authorities in Kamituga. This research would not have been possible without the artisanal miners of Kamituga who offered their time to be interviewed, the enumerators who worked in sometimes challenging circumstances, and our colleague Janvier Kilosho who assisted with the field work. We offer them our sincere gratitude. We further owe thanks to employees of Banro, SAESSCAM, IPIS and INSO for their assistance and for sharing valuable information. We are grateful for comments received at the Jan Tinbergen Peace Science Conference in Milan and den Haag, the UNU-MERIT Maastricht seminar, the conference on transition and local development in Eastern Congo in Bukavu, and the NOVAfrica conference in Lisbon. We received much appreciated comments from Jean-Paul Azam, Tom De Herdt, Joachim De Weerdt, Sara Geenen, Victoire Girard, Cliff Morgan, Enzo Nussio, Arinze Nwokolo, Dominic Parker, Anja Shortland, Jo Swinnen, Peter van der Windt, Pedro Vicente, Nina von Uexkull, Leonard Wantchekon and three anonymous reviewers. All errors and opinions expressed remain ours. 


\begin{abstract}
To meet the rising demand for minerals, mining companies have ventured into fragile areas, often at the expense of artisanal miners. This has led to grievances, and at times violence. Who among the aggrieved intend to use violence? How can peace be maintained? This paper uses individual-level data to address these questions. Among a sample of 469 about-to-be-evicted artisanal miners in Eastern Congo, we inquire about the intention to engage in several forms of violence. We identify how this intention varies with miners' past exposure to violence and attitudes towards policies that seek social peace. A large proportion of miners intends to destroy the company's property, attack its employees, use fire arms, or join an armed group. These would-be-fighters are motivated by grievances, as well as material and social incentives. Our results contribute to understanding the micro-motivations underpinning the local resource curse and entail concrete lessons for mining policies.
\end{abstract}




\section{Introduction}

"If you take 100 [artisanal] miners today, you may find 3 to 5 who were part of [the armed group] Shikito. But if we are all chased away in the future and Banro does not leave us with any alternative, everyone could join"

-- focus group discussion, Kamituga, December 2014

Since the 2000s super-cycle in commodity prices, the search for precious minerals has enticed large-scale mining companies to increasingly venture into fragile and conflict-affected regions, often crowding out artisanal miners (e.g. Campbell 2003; Haselip and Hilson 2005; Hilson and Yakovleva 2007). At the same time, it has been shown that the commodity super cycle contributed to violence in Africa, explaining up to one fourth of the continent's violent events over the period 1997-2010 (Berman et al. 2017). Stoop et al. (2019) show that these two facts are linked: the expansion of industrial mining in artisanal mining sites increases riots as well as violence against civilians. This paper looks more closely at this link. In particular, we study who among the evicted artisanal miners would turn to violence, and which policy measures can appease the would-be-fighters.

To do so, we turn to Eastern Democratic Republic of Congo (DRC), one of the most fragile (post-)conflict regions in the world, where an unprecedented expansion of large-scale mining is crowding out artisanal mining. We study a sample of 469 artisanal miners that are operating in Kamituga, a mining town located on a concession held by Banro, a Canada-based multinational. The miners are all (young) men; the vast majority was exposed to the violence of the Congo wars, and some participated in the violence. Their future is uncertain, facing eviction once the company moves to the production phase. It is to these men, who experienced violent conflict and were at risk of losing their employment, that we asked the question "would you fight?". We inquire about their intention to engage in four concrete violent actions: destroying the firm's property, attacking its employees, using fire arms and joining an armed 
group. We then relate miners' intention to participate in these actions to their past exposure to violence and their attitudes towards policies that seek to curb violent confrontations. The associations that emerge allow us to sketch the profile of 'would-be-fighters' and inform mining policies that aim to preserve (social) peace.

Our study is situated at the nexus of three strands of literature. First, it relates to the largely qualitative body of studies that highlights the tenuous relationship of industrial mining companies with artisanal miners (e.g. Bush 2009; Carstens and Hilson 2009; Geenen and Claessens 2013; van Puijenbroeck and Schouten 2013; Verweijen 2017). Second, our study adds to the growing literature that uses individual-level data to identify micro-motivations for participating in collective violence (e.g. Blattman and Annan 2016; Humphreys and Weinstein 2008; Nussio 2017), or for the intention to participate (e.g. Argo, 2009; Ginges and Atran, 2009; MacCulloch, 2004; Muller et al., 1991; Thyne and Schroeder, 2012). Third, we fit in with the local resource curse literature that studies the relation between the exploitation of natural resources and local conflict (e.g. Berman et al. 2017; Dube and Vargas 2013; Sanchez de la Sierra 2019).

We make three main contributions. To the first strand of literature, we add a quantitative study that assesses the effectiveness of mining (company) policies aiming to curb the risk of violence, such as Corporate Social Responsibility (CSR), local content, the militarized securitization of mining sites, and the reorientation of miners. The results of this assessment can inform corporate policies and the design of a country's Mining Code. Second, by analyzing the intention to fight of high-risk youth in a post-conflict environment, we empirically verify if and how past victimization and rebel networks are associated with the individual propensity to participate in violence. By doing so, we shed further light on the micro-dynamics underlying the recurrence of armed conflict. Third, to advance our understanding of the local resource curse, we descend to the individual (rather than national or local) level in order to test theories 
about individual behavior that could fuel violence. That individual-level data are needed to further unearth the local resource curse is clear from a brief review of relevant literature on Eastern Congo.

So far, two studies have looked at the relation between industrial mining and local violence in Eastern Congo, both relying on subnational georeferenced data. Maystadt et al. (2014) find that granting industrial mining permits increases conflict, but not in the vicinity of the mining concession. They explain this as a 'protection effect', arguing that mining companies have strong incentives to keep fighting activities away from their production sites. Analyzing various forms of local violence in over 2,000 grid cells, Stoop et al. (2019) find that, while the expansion of industrial mining indeed decreases battles in the vicinity of the concession, it increases the incidence of riots, and when the initiation of industrial production crowds out artisanal mining, it also leads to more violence against civilians and looting. Lacking individual data, these studies can however only speculate about the actors of the violence, and their micro-motivations. Is the violence being committed by rebels that were taxing the evicted artisanal miners, or by the artisanal miners themselves? In the latter case: does it involve a small minority of the artisanal mining community, or a large proportion? Do the poorest miners fight, seeking alternative sources of revenue; those most aggrieved; or those with a rebel network that can easily be activated? Are there policy measures that can curb the risk of violence?

We first present background information on mining in Eastern Congo and motivate our case selection. We then review the theoretical micro-motivations related to individuals' intention to fight, and propose hypotheses tailored to our case study. Next, we describe our data and method, followed by a presentation of the results. We conclude with a discussion of our main findings and policy implications. 


\section{Background}

\section{A. Artisanal and Industrial Mining in Eastern Congo}

Eastern Congo was the scene of the first and second Congo wars (1996-1997 and 1998-2003). Despite the formal end of war in 2003, violence continued. In 2015, the year of our interviews, more than seventy armed groups were active in Eastern Congo, and approximately 1.6 million people remained displaced (Stearns and Vogel 2015, 7). Eastern Congo is also home to many of the country's mineral deposits, mainly gold and $3 \mathrm{~T}$ minerals (tin, tungsten, and tantalum). In the colonial period, industrial large-scale mining (LSM) was the norm, but it disappeared due to mismanagement by Mobutu's regime and the two Congo wars.

Artisanal mining (ASM) ${ }^{1}$ gradually developed from the 1960s onward and accelerated after 1982, when Mobutu liberalized mineral exploitation. During the Congo wars, ASM continued to expand. After the war ended, former rebels further added to the ranks of artisanal miners (Vogel and Musamba 2016). In 2008, a (gu)estimate by the World Bank (2008) put employment in DRC's ASM sector in the range of 0.5 to 2 million miners, and a 2016-2018 mapping exercise counted 382,000 artisanal miners across 2,700 sites in Eastern Congo (Matthysen et al. 2019). ASM not only provides a living to artisanal miners and their dependents, but to a multitude of actors providing goods and services in and around the mines (Geenen 2014). Armed actors also benefit from ASM in Eastern Congo. In 2015, it was estimated that about $56 \%$ of ASM sites harboured armed actors ${ }^{2}$ that were taxing artisanal miners in return for protection against violence, including their own (Weyns et al. 2016). Conflict minerals legislation aiming to cut this source of financing for armed groups has backfired, leading to crime displacement (Parker and Vadheim 2017; Stoop et al. 2018), and a de-facto ban hurting artisanal miners and the local economy (Geenen 2012; Parker et al. 2016).

Putting further strain on ASM and the local economy it fuels, is the re-emergence of industrial mining. In 2002-3, new laws (the 2002 Mining Code and 2003 Mining Regulations ${ }^{3}$ ) 
were developed to attract foreign investments. In combination with the commodity price boom, the attractive fiscal conditions did not miss their effect: in the period 2004-2015, research permits granted to LSM companies increased more than tenfold and production permits about fourfold (Stoop et al. 2019). While the inflow of FDI has improved DRC's macro-economic performance, industrial mining has not generated much tangible benefits for the population. In contrast to ASM, the capital-intensive production mode creates little employment (Radley 2019), and struggles to establish forward and backward linkages with the local economy (Cassimon et al. 2016). Moreover, industrial mining often takes place in areas where artisanal miners are present, thus threatening existing employment. According to the Mining Code artisanal activities should take place in clearly demarcated Artisanal Exploitation Zones (AEZ). Very few AEZ were created however, in areas were (semi-)industrial mining is not feasible, technically or economically (see Panel A of Figure 1). ${ }^{4}$ As a result, in 2015 - the year of our data collection - only $1 \%$ of artisanal miners in Eastern Congo was operating in AEZ, while the majority operated 'illegally' in the rapidly expanding LSM concessions (Stoop et al. 2019). This can be seen by comparing Panels A and B of Figure 1, showing the location of LSM concessions, AEZ and ASM sites for 2015.

The World Bank, DRC's main partner in establishing the 2002 Mining Code, acknowledges the 'problem' of artisanal miners. In their 2008 report on 'Growth with Governance' in DRC's Mining sector, they state: “Licensed companies are facing huge social problems because these 'artisans' are reluctant to leave their only source of revenue. Clashes between them and the mine 'policemen' are frequent." (World Bank, 2008: p.125). That there are frequent clashes is also clear from a recent report by the (International Crisis Group 2020) and from Congolese news outlets that regularly report on demonstrations by artisanal miners, miners retaking mining sites, destructions of a company's property, and kidnappings of its

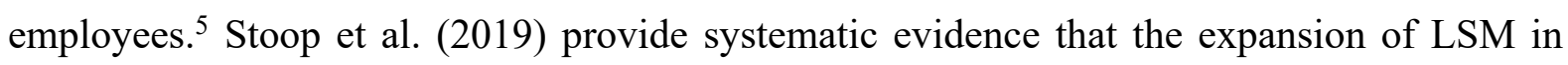


Eastern Congo triggers violence in areas where it crowds-out ASM. Regarding the timing of violence, they show that it mainly erupts when LSM companies move from the research to the production phase, thus coinciding with the relocation of local communities and the eviction of artisanal miners.

\section{B. Case Study}

To provide insight into the violence that accompanies LSM expansion in Eastern Congo, we travelled in the footsteps of Banro. In 2002 Banro acquired rights to the gold concessions of Kamituga, Lugushwa, Twangiza (in South-Kivu Province) and Namoya (in Maniema Province), combined covering over 5,000 km² (Banro 2014a). Panel C of Figure 1 shows the location of Banro's research and production concessions. In Twangiza and Namoya, the company moved to the production phase in 2011 and 2015, respectively, and subsequently faced fierce resistance by artisanal miners, the local population, and armed groups (Geenen and Claessens 2013; Verweijen 2017). On numerous occasions the resistance turned violent, including the destruction of Banro property; the forcible reoccupation of artisanal mining sites; violent attacks, ambushes and theft; and the kidnapping of Banro employees. ${ }^{6}$ As a result of the increasingly tense security situation, Banro evacuated its staff and temporarily suspended mining operations in Namoya in 2017 (Mining Review Africa 2017; Ross 2017). In 2019, the situation escalated. In July, militiamen kidnapped four Banro employees in Namoya. After a round of negotiations, Banro signed an agreement with the militiamen allowing artisanal miners to temporarily extract gold from a part of Namoya's mining site, in exchange for the release of the abducted employees (Radio Okapi 2019a; La Libre Afrique 2019). The situation remained tense however, and in September militiamen took control of the mine and threatened to kill any employee that reported to work. The company subsequently decided to suspend all activities in their four DRC mining sites (Radio Okapi 2019b), and started preparing an exit 
strategy. In January 2020, they sold their Twangiza concession to a Chinese company, and also put Namoya on offer (Holland 2020).

Our initial plan was to survey miners not only in Kamituga, but also in Twangiza where Banro had already moved to the production phase and miners resisted dislocation. However, during a field visit in 2015, the situation in Twangiza proved too tense to allow for independent research. We therefore decided to focus our attention on Kamituga, where the company had not yet moved to the production phase, and study the 'intention to fight'.

Kamituga is a mining town of about 130,000 inhabitants $^{7}$, located at 180 kilometers of the provincial capital Bukavu (see Panel C of Figure 1). Gold deposits were discovered in the 1920s and a Belgian company started commercial gold exploitation in the 1930s (Vlassenroot and Raeymaekers 2004). As elsewhere in post-independence Congo, industrial production eventually came to a halt, and artisanal mining got the upper hand. During the Congo wars, Kamituga was occupied by armed groups that were taxing artisanal miners and traders, and it was the scene of several atrocities (Geenen 2014). To defend the town and its minerals against (foreign) occupation, a self-defense group was created: 'Mai-Mai Shikito' (Harvard Humanitarian Initiative 2009). Allegedly created by the vice-president of a local mining committee, it consisted mainly of miners from Kamituga (focus group discussion, December 2014). According to our focus group discussions, most of Shikito's members had returned to mining by 2015 , but reportedly still had their arms at home and could take them up when necessary (see e.g. quote at the start of this paper). After the wars, armed actors continued to benefit from Kamituga's artisanal mining sector. The Congolese national army took over the existing taxation systems, while the armed group FDLR (Forces Démocratiques pour la Libération du Rwanda) remained active in Kamituga's surroundings setting up 'tax barriers' and relying on ambush attacks against mineral traders (UN 2010). 
Banro started its research phase in Kamituga in 2011. At the time of our interviews, in 2015, the company was hoping to move to the production phase. Between 13,000 and 15,000 artisanal miners were however operating within its concession. ${ }^{8}$ While still tolerating artisanal miners, Banro already restricted their activities. Certain areas were off limits, and miners were not allowed to open new pits, or make use of dynamite, crushing mills and electricity - all of which enhance the productivity of artisanal mining. To enforce these rules, Banro mainly relied on the Mining Police and at times on the Congolese national army; but artisanal miners continued to bend the rules, at times with the complicity of the same security forces (Kilosho Buraye et al. 2017). In an attempt to maintain good relations with the population and artisanal miners in its concession, Banro invested in public goods and services, such as roads, hospitals and schools (Banro 2014b), and looked to employ Congolese individuals, preferably from the local mining communities. The company also sought to collaborate with the Congolese Ministry of Mines and its public Service for Assistance to Artisanal and Small-Scale mining (SAESSCAM) to facilitate the creation of an officially registered Artisanal Exploitation Zone within their concession, where ASM would be tolerated even during Banro's production phase (Kilosho Buraye et al. 2017). Furthermore, Banro set up a partnership with USAID intended to roll out relocation and reorientation projects for artisanal miners (Banro 2014b). While Banro hoped that these initiatives would give them a 'social licence to operate', there were several challenges to overcome. As such, the training and employment programs - often managed through subcontracting with local elites - were temporary, low-skilled, low-paid, plagued by corruption, and could only reach a small share of artisanal miners, thus oftentimes increasing rather than decreasing grievances (Geenen and Claessens 2013; Kilosho Buraye et al. 2017; Verweijen 2017).

\section{Why (Not) Fight?}


In this section we first give a brief overview of the different theoretical micro-foundations explaining individual participation in collective violence. From the theory, we formulate hypotheses tailored to two features of our case study: (1) the post-conflict context and (2) policies implemented by mining companies to obtain (social) peace.

We apply the theoretical micro-foundations from a longstanding scholarly debate. A first school of thought focusses on grievances and feelings of discontent as the drivers of rebellious action (e.g. Gurr 1970; Lichbach 1989). Influenced by Olson's (1965) analysis of collective action, a second school of thought argues that rational individuals only participate when their personal benefits from participation outweigh the costs. Two types of 'selective incentives' may influence the cost-benefit analysis. Material incentives include financial and other material benefits from participation, as well as having low opportunity costs (Blattman and Annan 2016; Collier and Hoeffler 1998; Lichbach 1995; Tullock 1971). Social incentives emphasize the importance of an individual's social network. They are largely psychological in nature. For instance, participation in rebellious collective action may yield social rewards stemming from feelings of solidarity with a group and conforming to a social norm (e.g. Muller et al. 1991; Muller and Opp 1986). Finally, whether individuals are driven by material or social incentives, they will be more likely to participate if the rebellion is feasible, i.e. when the probability in attaining success is (perceived to be) high (Bandura 1973; Muller and Opp 1986). In a post-war context, the latter two theoretical micro-foundations are especially salient: social incentives and perceived feasibility. Individuals may have access to a rebel network, may have been exposed to violent events, or had experience with (failed or successful) armed activities. Since social incentives stem from feelings of solidarity with a group and gratification from conforming to a social norm, having ties with rebels may increase the likelihood of participation in collective violent action; as found for instance by Humphreys \& Weinstein (2008) in Sierra Leone's civil war. Such ties not only expose individuals to norms that value 
violent resistance but may also simply increase the feasibility of mobilizing a critical mass of armed companions. Experiences of victimization may add to the social incentives to fight. Building on evolutionary theories of human behavior, a growing literature demonstrates that exposure to conflict may increase prosocial preferences towards those with whom one identifies but not to out-group members (e.g. Bauer et al. 2014; Beber et al. 2014; Choi and Bowles 2007; Gneezy and Fessler 2011; Voors et al. 2012). Such parochial preferences increase the willingness to cooperate with the in-group, thus affecting the social benefits of participation in collective violence. Regarding the post-war context of our case-study, we therefore hypothesize that miners are more likely to report an intention to fight if:

1. They have access to a rebel network

2. They were exposed to violent events

3. They perceive past violent opposition as successful

Mining (company) policies mainly try to address the first two micro-motivations mentioned above: grievances and material incentives. As such, corporate social responsibility programs that provide local communities with public goods and services aim to reduce grievances (World Bank 2009). 'Local content' policies that increase the number of local employees may also assuage grievances, as well as reduce the opportunity cost to fight. Both these micro-motivations are also addressed when companies tolerate miners in some parts of their concession, or set up programs to relocate or reorient artisanal miners (Kilosho Buraye et al. 2017). The effectiveness of the corporate initiatives depends however to a large extent on the capacity and trustworthiness of the local institutions that are relied upon for the implementation (Geenen 2019). Finally, besides carrots, companies also use sticks to protect their investment, hiring private security companies, and - in the case of DRC - also relying on the Congolese Mining Police and at times the national army (Verweijen 2017). Based on this 
overview of carrots and sticks, we hypothesize that miners are less likely to report an intention to fight if:

4. They are more positive about the company's CSR programs

5. They are interested in working for the company

6. Their artisanal mining activities are tolerated by the company

7. They are willing to relocate

8. They are willing to reorient

9. They trust local mediating institutions

10. They fear the security forces that protect the company's property

We will operationalize these hypotheses in a regression framework, including additional elements as controls. A first set of control elements affects both grievances and the opportunity cost to fight: asset wealth, schooling, and whether the household has an income source outside the mining sector (see e.g. Blattman and Annan, 2016; Humphreys and Weinstein, 2008). As pit managers earn considerably more (Geenen et al., 2020), we further control for miner's function in the pit as a proxy for how much they stand to lose should artisanal mining no longer be possible. Finally, we consider family and community ties. According to social control theory, these factors produce conformity with norms, and may thus refrain or encourage actors from participating in collective violence (Thyne \& Schroeder, 2012).

\section{Data \& Method}

This section has four parts: we (A) describe the data collection process; (B) explain how we measure miners' intention to fight; (C) present the explanatory variables; and (D) set out our estimation method.

\section{A. Data Collection}


We aimed to reach a representative sample of artisanal miners in Kamituga. As there was no reliable list that would allow us to draw a random sample, we had to establish one. To do so, we took advantage of the hierarchical structure of the mining site, which is divided in different zones (headed by 'zone managers'), that consist of several mining pits, each operated by a close-knit team of miners (supervised by a 'pit manager'). We first created a list of all active mining zones in Kamituga. From the resulting list of forty zones, we selected nine, seeking variation in terms of suitability for industrial exploitation, i.e. whether or not the zone was of direct interest to Banro. In a second step, we asked zone managers in selected zones to provide us with a list of all pit managers, who in turn provided us with a list of all miners working with them. The complete list for the nine zones consisted of 1,254 miners, working in 72 pits. We randomly selected half of the pits in each zone, and randomly selected ten miners in each of the selected pits. Pit managers of selected pits were also included. Our final sample comprises 430 miners and 39 pit managers.

All respondents were individually interviewed with a structured survey, implemented in May 2015. To elicit truthful and accurate answers, we strongly invested in establishing a relationship of trust. To do so, we relied on the extensive local network of a colleague who had been working with miners in the area for over five years (see e.g. Geenen 2014). Moreover, we conducted two rounds of exploratory fieldwork, in June and December 2014, to gain a good understanding of the research context, test the applicability of our questions and build the necessary trust and network. Each interview started with a careful introduction in which we presented ourselves, the research and its purpose. We guaranteed anonymity as well as the option to refuse to respond to questions or abort the interview at any point. Although the situation in Kamituga was relatively safe, it was not safe enough to walk around with a lot of cash. In the absence of a single bank in Kamituga, we dropped most of the incentive-compatible games that we designed to measure attitudes (such as trust, fairness and cooperation). On the 
other hand, many questions we expected to be sensitive were not. Most prominently, during the exploratory rounds of fieldwork we noticed that miners freely talked about their intention to fight. Hence, we decided to drop the 'list experiment' ${ }^{9}$ we designed and asked the question directly - the next section provides detailed information in that regard. The survey team was selected from a pool of enumerators with extensive experience. The complete survey and all survey instruments can be consulted online..$^{10}$

\section{B. Intention to Fight}

We framed the intention to fight as a reaction against Banro. We asked our respondents to imagine the following realistic scenario: "Imagine a situation where Banro moves to the production phase in Kamituga. Imagine that they organize professional training programs and authorize some artisanal miners to continue operating in selected mining sites at Kamituga. However, their budget is not sufficiently large to accommodate all miners in the training programs, and the selected mining sites are not sufficiently large to accommodate all artisanal miners." We asked if such a situation would lead to a conflict between the company and artisanal miners. Answer categories included: refuse to respond (0), certainly not (1), probably not (2), maybe (3), probably (4) and certainly (5). We additionally asked if they thought the conflict would be violent. The majority of miners indicates that the above scenario would certainly lead to a conflict (72\%) and that it would be violent (64\%).

Next, we presented each respondent with four violent actions, inquiring about their intention to engage in them: (1) destroying Banro property; (2) attacking Banro employees; (3) using fire arms; and (4) joining or revitalizing an armed group or local defense force ("like Mai-Mai Shikito"). Panel A of Figure 2 displays the answer distribution, indicating that a substantial group of miners would 'probably' or 'certainly' destroy Banro property (48\%), attack Banro employees (36\%), use fire arms (29\%), or join an armed group (19\%). From these 
answers, we construct two indicator variables that proxy the individual intention to fight. The first equals one for miners who display a 'probable' or 'certain' intention to destroy Banro property, attack Banro employees and use fire arms. This is the case for 108 miners or $23 \%$ of the sample. A second proxy looks at a more organized form of violence, and equals one for miners who additionally display a 'probable' or 'certain' intention to join an armed group. This is the case for 61 miners or $13 \%$ of the sample. Panel B of Figure 2 visually presents these two proxies.

As mentioned above, our exploratory fieldwork indicated that questions gauging miners' intention to fight were not considered sensitive. We therefore dropped the list experiment. We are in fact more concerned about over- than under-reporting. Over-reporting of one's intention to fight could occur because of strategic considerations (to intimidate the company), social desirability (peer pressure to participate in collective violence), or because participating in violence is costly and risky, and the effect of the actual costs may only set in when decision time has come. Reassuringly however, the high intention to fight reported by our respondents is consistent with the behavior of miners observed in the two concessions where Banro already moved to the production phase (Twangiza and Namoya), and in other mining sites across Eastern Congo (as reported in the various news articles cited in the background section). It is further in line with the findings of Stoop et al. (2019) - who measure substantial size effects of the expansion of LSM on violence in Eastern Congo: when industrial mining companies expand their production concessions to cover an additional 10 percentage points of a cell's surface area, the incidence of riots increases with $39 \%$; and, for every additional artisanal mining site that is located within the boundaries of an expanding production concession, the incidence of violence against civilians and looting increases with $21 \%$ and $31 \%$, respectively. Given all of the above, we argue that our measures pick up meaningful variation in the intention to fight. 


\section{Determinants of the Intention to Fight}

Below we describe the variables that allow us to test the hypotheses listed above. Table 1 gives an overview of summary statistics.

\section{Access to rebel network}

We asked respondents if they ever participated in the activities of an armed group: $3.2 \%$ indicated they had. To measure 'access to rebel network', we rely on the fact that miners closely collaborate in a mining pit. We define a variable indicating whether a miner works in a mining team that includes at least one self-reported (former) rebel. This is the case for $29 \%$ of our respondents.

\section{Past exposure to violence}

We inquired about exposure to eight different violent events (Table 1 presents summary statistics). Nearly all (93\%) respondents were exposed to at least one of these events. In our main specification, we include an indicator variable that captures exposure to, arguably, the most extreme conflict event: having witnessed killings or rape ( $29 \%$ of respondents). We conduct sensitivity checks with indicators for exposure to other types of violence (see Robustness Checks).

\section{Past violent opposition perceived as successful}

To measure the perceived success of previous violent resistance, we asked respondents to evaluate the impact of Mai-Mai Shikito's actions on the well-being of miners in Kamituga. The answer categories included: very negative (1), rather negative (2), no effect (3), rather positive (4), very positive (5). We create an indicator variable that equals one for the $14 \%$ of miners that indicate Mai-Mai Shikito had a rather or very positive impact.

\section{Positive opinion on company's corporate social responsibility}


We asked to what extent respondents agreed with the following statement about Banro's contributions to community development: "Banro is important for the development of Kamituga". Answer categories included: strongly disagree (1), rather disagree (2), indifferent (3), rather agree (4), strongly agree (5). Only a minority of miners (18\%) indicates that Banro is rather to very important for the development of Kamituga. We created an indicator variable capturing these miners.

\section{Interested in working for the company}

We asked respondents whether they would be interested in working for Banro if artisanal mining would no longer be possible in Kamituga. Answer categories included: very interested (1), interested (2), rather indifferent (3), not interested (4). Just over half of the miners (55\%) expressed interest, choosing options (1) or (2). We create an indicator variable that equals one for these miners.

\section{Artisanal activities are tolerated by the company}

As mentioned above, we stratified our sample across zones better and less suited for industrial exploitation. The zones of interest to the company were more frequently visited by Banro employees, for geological exploration but also to enforce the more stringent restrictions that applied in these zones. In the other zones, ASM enjoyed more tolerance. To capture the variation in perceived tolerance, we asked respondents how often Banro employees visited their zone in the month prior to the interview. Answers range from 0 to 31, with an average of 3.

\section{Willing to relocate}

We asked miners about their willingness to migrate (to an AEZ) in order to continue their ASM activities: "Should artisanal mining no longer be possible in Kamituga, would you consider migrating towards an AEZ to continue ASM if the AEZ is located in the chefferie of Wamuzimu”. The answer categories ranged from (1) No, to (5) Very likely. The miners are 
very divided on this issue: while $36 \%$ find this (very) unlikely, $52 \%$ find it (very) likely. We create an indicator variable that equals one for the latter group of miners.

\section{Willing to reorient}

To assess miners' willingness to reorient to other economic activities, we measured their reservation wage, i.e. the wage at which they would be willing to switch from artisanal mining to an alternative activity. ${ }^{11}$ Specifically, we asked miners if they would be willing to quit ASM and take up an alternative activity, while varying the daily wage associated with the alternative activity $(\$ 1, \$ 5, \$ 10, \$ 15, \$ 20)$. We find that only a very small share of miners $(3 \%)$ indicate they would very likely quit ASM for another activity that yields $\$ 1$ per day. The large majority of miners $(87 \%)$ would do so for $\$ 20$ a day. We create a categorical variable indicating the wage at which miners would 'very likely' be willing to reorient; setting it at $\$ 30$ for miners whose reservation wage exceeds $\$ 20$. The variable thus ranges from 1 to 30 , with an average of 14 .

\section{Positive opinion on local institutions}

We distinguish six relevant local institutions that could defend miners' interests in negotiations with Banro, or function as intermediaries of the company's training and employment programs: the 'Chef de Poste' (contemporary local authority), the 'Mwami' (traditional leader), Kamituga's main mining cooperatives (COKA and CRC), SAESSCAM and the Congolese Mining Division. Respondents were asked their opinion on each of these institutions: "How do you think these actors contribute to the well-being of artisanal miners?" The answer categories included very negative (1), rather negative (2), no effect (3), rather positive (4), very positive (5). Miners were most positive about COKA (3.9) and most negative about the mwami (2.7). Pooling the answers across the six institutions, the institutions score 3.2, on average.

10. Fear the security forces that protect the company's property 
The same question was asked regarding the Mining Police (score of 2.71) and the Congolese Army (score of 2.63), both of which intervene on the company's behalf to enforce the restrictions put in place, or curb (violent) demonstrations. Combined, they score 2.67 on average. As indicated in the background section, the security forces sometimes collude with artisanal miners, allowing them to by-pass restrictions. This may explain why a minority of miners $-27 \%$ for the Mining Police and $16 \%$ for the Congolese Army - state that these security forces positively contribute to the well-being of artisanal miners. We assume that the more positive miners' opinion, the less fearful they would be of them should it come to a violent confrontation. After all, in the absence of perfect monitoring by Banro, the security forces can exert 'agency', even in a (violent) confrontation with the miners.

\section{Estimating Equation}

We test our hypotheses by estimating the following equation:

$$
F_{I G H T_{i z}}=\alpha_{0}+E_{i z}^{\prime} \mathrm{A}+C_{i z}^{\prime} \mathrm{B}+Z_{z}^{\prime} \Theta+\varepsilon_{z}
$$

where $i$ indexes the 469 miners and $z$ the 9 mining zones. The outcome variables, denoted by FIGHT $_{i z}$, are the two proxies for a miner's intention to fight and rebel (Panel B of Figure 2). $E_{i z}^{\prime}$, is a vector containing the ten explanatory variables listed above, while $C_{i z}^{\prime}$ contains the control variables. To account for unobserved characteristics that may influence miners operating in a particular zone, we add mining zone fixed effects $\left(Z_{z}^{\prime}\right)$. Standard errors $\left(\varepsilon_{z}\right)$ are clustered at the level of mining zone to account for within-zone correlation of residuals. The equation is estimated using a probit model, but we provide robustness checks with different estimation methods.

It is likely that unobserved characteristics simultaneously influence the explanatory variables and miners' intention to fight. Lacking a suitable instrument for identifying 
exogenous variation, we turn to the procedures suggested by Oster (2019) to formally assess the threat of omitted variable bias.

\section{Results}

\section{A. Main Findings}

Table 2 presents the estimation results with and without mining zone fixed effects. Here we focus on results from the most inclusive specifications that include mining zone fixed effects and clustered standard errors (see Columns 2 and 4 of Table 2).

The findings indicate that 'social incentives' and 'feasibility' play a role. Having access to a rebel network appears to be particularly important. We find that miners operating in a pit with a self-reported (ex-)combatant are more likely to report an intention to engage in violent actions against Banro (12 percentage points) and to join an armed group (12 percentage points). These findings are significant at the $1 \%$ significance-level in all specifications. We also find strong effects for conflict exposure. Miners who witnessed killing or rape display a significantly higher intention to engage in violence against Banro (11 percentage points) and join an armed group (8 percentage-points). The self-reported intention to fight further rises when past violent opposition is perceived as successful. Miners who positively evaluate MaiMai Shikito's actions display a higher intention to engage in violence against Banro and join an armed group (9 percentage points) - but these findings are no longer significant after including mining zone fixed effects and clustering standard errors.

We further find empirical support for the role of 'grievances' and 'material incentives'. Respondents perceiving Banro's contribution as important for the well-being of Kamituga's population are 10 percentage-points less likely to participate in violent actions against the company, and 12 percentage points less likely to join an armed group (significant at the 1\%level). Miners that are interested in working for Banro are 6 percentage points less likely to 
display an intention to join an armed group (significant at the 5\%-level), but are not significantly less likely to participate in violent actions against the company. The intention to fight increases however with the degree to which ASM activities are being restricted. With each additional visit that Banro employees make to a mining zone, miners' intention to attack the company and join an armed group rises (by 0.7 and 0.8 percentage points respectively, both significant at the $1 \%$-level). The willingness to relocate or reorient has no statistically significant effect on the intention to fight, and the coefficient estimates are close to zero. We do find some evidence that trust in local institutions matters: a positive opinion regarding local mediating institutions is associated with a lower intention to join an armed group ( 3 percentage points), but only at the $10 \%$-level. ${ }^{12}$ In contrast, a more positive opinion regarding the security forces is related with a higher intention to engage in violence against Banro ( 7 percentage points) and to join an armed group ( 3 percentage points). These findings, significant at the $5 \%$ level, suggest that when security forces are perceived to side with the miners, they are less fearful of them should it come to a violent confrontation.

Moving to the control variables, we find that mining function, asset wealth, the level of education, being born in Kamituga and being single do not significantly impact the intention to fight. We do find that respondents who are less reliant on their mining income display a lower intention to fight: having an additional income source, besides mining, at the householdlevel is associated with a lower intention to engage in violence against Banro (by 5 percentage points) and join an armed group (by 5 percentage points). Household composition also seems to matter: respondents living together with their young children are 7 percentage points less likely to display an intention to join an armed group, but do not have a significantly lower intention to use violence against Banro. Finally, younger miners show a higher willingness to fight: the intention to engage in violence against Banro and join an armed group decrease by 0.5 and 0.3 percentage points, respectively, with each additional year of age. 


\section{B. Correlation Versus Causation}

Given the lack of exogenous variation, the above results merely provide evidence of correlations, not of causal relations. The main difficulty to infer causation lies with miners' unobserved characteristics that may influence both the explanatory and dependent variables, causing spurious correlation. This is particularly relevant in the case of previous conflict exposure and having a rebel network. Conflict exposure only partly relates to random bad luck, and partly to unobserved war-time decisions and behavior of our respondents. Moreover, miners with a larger rebel network may be more likely to have participated in activities of armed groups themselves, even if they report otherwise. Past participation, except in the case of forced recruitment, clearly is a decision variable and thus prone to endogeneity.

To formally assess omitted variable bias, we follow the approach suggested by Oster (2019). It uses selection on observable variables as a guide to assess potential bias from unobserved variables. Selection on observables is assessed by looking at coefficient movements in the estimates of conflict exposure and rebel networks while gradually adding additional control variables. The relevance of the control variables is assessed by evaluating the associated movements in the R-squared. Put very simply: if adding a battery of relevant observables does not affect our coefficients of interest much, then the confounding effect of unobservables would have to be large, relative to that of observables, to completely cancel out our results. Based on these insights, Oster (2019) developed a measure that indicates how large selection on unobservables has to be, relative to selection on observables, to fully explain away the estimated effect. ${ }^{13}$ As a cut-off for robustness to omitted variable bias, the approach takes a value of one: indicating that selection on unobservables is equally important as selection on observables. For having a rebel network, we find that selection on unobservables would have to be three to five times larger than selection on the included variables to fully explain away our estimated effects. For conflict exposure we find even stronger results, indicating that 
selection on unobserved covariations would have to be between 9 and 13 times larger than selection on the included covariates. These results suggest that our qualitative conclusions are not sensitive to omitted variable bias. Appendix 2 provides detailed information on the methodology and presents the results in Table A.3.

\section{Robustness Checks}

We run six checks to gauge the robustness of our findings. Results are presented in Appendix 2.

Above we presented the most inclusive model specifications. As a first robustness check, Tables A.2 and A.3 present estimation results where we move from parsimonious to more inclusive model specifications. Our findings remain stable.

Second, we address the issue that our model includes only nine clusters (mining zones), potentially biasing our findings. As suggested by Cameron and Miller (2015), we implement the wild cluster bootstrap method. Overall the results remain qualitatively unchanged (Table A.4).

Third, we estimate equation 1 with a logit estimation and a linear probability model. The main findings remain qualitatively unchanged (Table A.5).

A fourth robustness check relates to our proxy for conflict exposure. In the main specification, we include an indicator variable for having witnessed killings or rape (29\% of respondents). We explore the sensitivity of our findings by estimating eight versions of equation 1, each time using a different indicator for conflict exposure. We find that two other types of conflict exposure turn up significant: being forced to give away revenue or goods under armed threat; and being physically hurt during armed combat (Table A.6).

Our proxy for having access to a rebel network - working in a pit with a self-reported former rebel - may suffer from the reflection problem (Manski 1993). Moreover, self-reported former rebels are much more likely to have witnessed killings or rape $(67 \%$ vs $28 \%)$. As a fifth 
robustness check, we therefore exclude self-reported former rebels from the sample. Results remain unchanged (Table A.7).

A final robustness check relates to our outcome variables. In the main specification we create two indicator variables that proxy for the intention to fight and rebel. We test the sensitivity of our findings, by estimating equation 1 for each of the four violent actions that were presented to the miners: (1) destroying Banro property; (2) attacking Banro employees; (3) using fire arms; and (4) joining or revitalizing an armed group or local defense force ("like Mai-Mai Shikito"). The results indicate that the determinants related to the post-war context of our case-study (having a rebel network; previous conflict exposure; and perception of past violent opposition) only significantly affect the intention to use fire arms and join an armed group. Participation in these two violent actions stands out in the sense that it may require a higher degree of organization and connections, both of which may be acquired through past war experiences (Table A.8).

\section{DISCUSSION}

"Mining companies are heading to the ends of the earth to meet demand" (Hunter 2017, 1). This quote illustrates what motivates this paper. China's fast industrialization process triggered a commodity price super-cycle, which put in motion an unprecedented global scramble for minerals, leading companies to invest in fragile and conflict-affected regions. In these locations, companies often face resistance from local communities and artisanal miners, who seek to defend their land and livelihood. In the absence of reliable (state) institutions that can peacefully mediate a social contract, such resistance can turn violent.

We studied the intention to fight of about-to-be-evicted artisanal miners in a fragile post-war area in Eastern Congo. The results of our regression analysis suggest scope for at least three mining company policies to reduce the intention to fight: credible CSR programs that 
effectively provide benefits to the local community, 'local content' policies that provide company jobs for artisanal miners, and setting up 'ASM-tolerant zones' within the company's concession. Our results are less supportive for reorientation and relocation programs, perhaps because the (perceived) effectiveness and fairness of such programs is rather low. These findings are corroborated by responses to an open question in our survey. We presented miners with six policy measures and asked them to what degree they agreed these might help preserve social peace (see Figure 3). The answer distributions are in line with our regression results: while the majority is in favor for 'local content' policies (82\%) and setting up 'ASM-tolerant zones' $(75 \%)$, answers are much more mixed when it comes to reorientation and relocation policies.

Regarding the post-conflict context, both miners' access to rebel networks and past victimization turn out to be strong predictors of the intention to fight, which suggests that the 'conflict trap' is unlikely to be driven only by post-war poverty; instead psychological and social processes likely play a role as well. These results indicate that it is extremely important to think through the design of mining policies, especially in post-war countries.

In recent years, dozens of African countries modified their mining codes to make LSM more attractive and bring in the necessary foreign exchange. But, the revisions were disconnected from reality, treating ASM as an afterthought even in countries where it constituted a major source of livelihood (Carstens and Hilson 2009). The neglect of ASM fits with the narrative that naively treats ASM as conflict-prone (Autesserre 2012; Laudati 2013), but our results show that LSM is not per se peace-prone, particularly not in areas where it is crowding out ASM. In terms of policy recommendations, to keep Eastern Congo and similar fragile mineral-rich areas safe, our findings support policies that formalize and accommodate - instead of crowd out - ASM; as well as policies that push for more CSR and local content. ${ }^{14}$ State-building is a 'conditio sine qua non'. Without effective and honest institutions, corporate 
policies not only fail to reach the eligible beneficiaries, but communities will also feel they need to take their protection in their own hands. 


\section{FOOTNOTES}

${ }^{1}$ The term ASM incorporates both artisanal and small-scale mining. In small-scale mining, mineral extraction is partly mechanized. In this study, ASM refers to artisanal mining only.

2 The Congolese army was present in $38 \%$ of ASM sites, while in $25 \%$ of sites the armed presence consisted of various rebel groups and local self-defence militias ('Mai-Mai groups').

${ }^{3}$ The mining code was again revised in 2018. Both the 2002 and 2018 codes are available online (http://congomines.org/reports).

${ }^{4}$ DRC Mining Code 2002, Title IV, Chapter I, Article 109.

${ }^{5}$ Consider for instance these headlines on Radio Okapi (https://www.radiookapi.net/): "Bunia: 3,000 Artisanal Miners Protest Against Their Forced Displacement in Mungwalu." July 7, 2015; "Kolwezi: Bloody Clash Between Artisanal Miners and Policemen." September 27, 2007; "Lualaba: Nearly 10,000 Artisanal Miners Invade the Tenke Fugurume Site.” November 21, 2016; and related to Banro: "Maniema: A Conflict Between Artisanal Gold Miners and the Police Cripples Activities in Salamabila." September 15, 2012; "Maniema: A Human Rights Activist Shot in Salamabila." January 26, 2016; "Maniema: Seven Employees of a Mining Company Taken Hostage in Salamabila." March 9, 2017; "Salamabila: At least 30 Dead in Fights Between the Army and Militia.” May 25, 2018.

${ }^{6}$ See for instance the last four Radio Okapi headlines of footnote 5.

${ }^{7}$ At the time of our survey, the latest population census estimated the number of inhabitants at 187,000 (Interview with local administrator of Kamituga, 2015). This census covered the entire health zone of Kamituga, including neighboring villages. For the city of Kamituga, the number of inhabitants was probably around 130,000.

${ }^{8}$ Representatives of local mining committees communicated that a census undertaken in 2013 counted 13,600 artisanal miners. During fieldwork in 2015 we counted 15,250 artisanal miners on the combined membership lists of two local mining committees. 
${ }^{9}$ List experiments are a tool to elicit truthful answers regarding sensitive topics (see for instance Blair and Imai, 2012).

${ }^{10}$ www.nikstoop.com

${ }^{11}$ The reservation wage can also be taken as a proxy for how much miners stand to lose should artisanal mining no longer be possible.

12 Additional regressions including separate indicators for each institution suggest that this effect is driven by miners' opinion regarding the traditional leader ('Mwami') and the contemporary local authority ('Chef de Poste'). Results are not reported but available upon request.

13 The calculations can be performed with the Stata command 'psacalc', provided by Oster (2019) and available through Stata's ssc.

${ }^{14}$ Compared to the 2002 Congolese mining code, the 2018 code imposes more obligations on LSM companies in terms of community development (title XI, Chapter IV, Article 285), and allows for the creation of an AEZ within an LSM concession (Title II, Chapter II, Article 30). Yet, it remains the case that AEZs are only established where industrial or semi-industrial mining are technically impossible or economically not opportune, which still confines ASM to a few marginal mining areas (Title IV, Chapter I, Article 109 of the 2018 code). 


\section{REFERENCES}

Argo, Nichole. 2009. "Why Fight? Examining Self-Interested Versus Communally-Oriented Motivations in Palestinian Resistance and Rebellion." Security Studies 18 (4): 65180.

Autesserre, Séverine. 2012. "Dangerous Tales: Dominant Narratives on the Congo and Their Unintended Consequences." African Affairs 111 (443): 202-22.

Bandura, Albert. 1973. Aggression: A Social Learning Analysis. Prentice Hall PTR.

Banro. 2014a. "2013-2014 Annual Information Form.” Banro Corporation. . 2014b. "2014 Sustainability Report: A 360 Approach to Sustainability.” Banro Corporation.

Bauer, Michal, Alessandra Cassar, Julie Chytilová, and Joseph Henrich. 2014. "War's Enduring Effects on the Development of Egalitarian Motivations and In-Group Biases." Psychological Science 25 (1): 47-57.

Beber, Bernd, Philip Roessler, and Alexandra Scacco. 2014. "Intergroup Violence and Political Attitudes: Evidence from a Dividing Sudan." The Journal of Politics 76 (3): 649-65.

Berman, Nicolas, Mathieu Couttenier, Dominic Rohner, and Mathias Thoenig. 2017. "This Mine Is Mine! How Minerals Fuel Conflicts in Africa." American Economic Review 107 (6): 1564-1610.

Blair, G., and K. Imai. 2012. "Statistical Analysis of List Experiments." Political Analysis 20 (1): 47-77.

Blattman, Christopher, and Jeannie Annan. 2016. "Can Employment Reduce Lawlessness and Rebellion? A Field Experiment with High-Risk Men in a Fragile State." American Political Science Review 110 (1): 1-17.

Bush, Ray. 2009. "'Soon There Will Be No-One Left to Take the Corpses to the Morgue': Accumulation and Abjection in Ghana's Mining Communities." Resources Policy, 34 (1): 57-63.

Cameron, A. Colin, and Douglas L. Miller. 2015. "A Practitioner's Guide to Cluster-Robust Inference." The Journal of Human Resources 50 (2): 317-72.

Campbell, Bonnie. 2003. "Factoring in Governance Is Not Enough. Mining Codes in Africa, Policy Reform and Corporate Responsibility." Minerals \& Energy - Raw Materials Report 18 (3): 2-13.

Carstens, Johanna, and Gavin Hilson. 2009. "Mining, Grievance and Conflict in Rural Tanzania." International Development Planning Review 31 (3): 301-26.

Cassimon, Danny, Karel Verbeke, and Marijke Verpoorten. 2016. "FDI from a 'Financing for Development' Perspective. Opportunities for Africa's Great Lakes Region.” Reflets et Perspectives de La Vie Économique Tome LV (1): 29-46.

Choi, Jung-Kyoo, and Samuel Bowles. 2007. "The Coevolution of Parochial Altruism and War." Science 318 (5850): 636-40.

Collier, Paul, and Anke Hoeffler. 1998. "On Economic Causes of Civil War." Oxford Economic Papers 50 (4): 563-73.

Dube, Oeindrila, and Juan F. Vargas. 2013. "Commodity Price Shocks and Civil Conflict: Evidence from Colombia." The Review of Economic Studies 80 (4): 1384-1421.

Geenen, Sara. 2012. "A Dangerous Bet: The Challenges of Formalizing Artisanal Mining in DRC." Resources Policy 37 (3): 322-30.

.2014. "'Qui Cherche, Trouve' the Political Economy of Access to Gold Mining and Trade in South Kivu, DRC." 
2019. "Gold and Godfathers: Local Content, Politics, and Capitalism in Extractive Industries." World Development 123 (November): 104605.

Geenen, Sara, and Klara Claessens. 2013. "Disputed Access to the Gold Sites in Luhwindja, Eastern DRC." Journal of Modern African Studies 51: 85-108.

Geenen, Sara, Nik Stoop, and Marijke Verpoorten. 2020. "How Much Do Artisanal Miners Earn? An Inquiry among Congolese Gold Miners." Resources Policy in press (October): 101893.

Ginges, Jeremy, and Scott Atran. 2009. "What Motivates Participation in Violent Political Action: Selective Incentives or Parochial Altruism?” Annals of the New York Academy of Sciences 1167 (1): 115-23.

Gneezy, Ayelet, and Daniel M. T. Fessler. 2011. "Conflict, Sticks and Carrots: War Increases Prosocial Punishments and Rewards." Proceedings of the Royal Society B: Biological Sciences.

Gurr, R.T. 1970. Why Men Rebel. Princeton University Press.

Harvard Humanitarian Initiative. 2009. "Characterizing Sexual Violence in DRC. Profiles of Violence, Community Responses, and Implications for the Protection of Women." Harvard Humanitarian Initiative.

Haselip, James, and Gavin Hilson. 2005. "Winners and Losers from Industry Reforms in the Developing World: Experiences from the Electricity and Mining Sectors." Resources Policy 30 (2): 87-100.

Hilson, Gavin, and Natalia Yakovleva. 2007. "Strained Relations: A Critical Analysis of the Mining Conflict in Prestea, Ghana." Political Geography 26 (1): 98-119.

Holland, Hereward. 2020. "Canadian Miner Banro Looking to Sell Congo Gold Mine at Discount: CEO.” Reuters. February 7, 2020.

Humphreys, Macartan, and Jeremy M. Weinstein. 2008. "Who Fights? The Determinants of Participation in Civil War." American Journal of Political Science 52 (2): 436-455.

Hunter, David. 2017. "Mining for Growth. Mining Companies Are Heading to the Ends of the Earth to Meet Demand." McKinsey Podcast. McKinsey \& Company.

International Crisis Group. 2020. "Mineral Concessions: Avoiding Conflict in DR Congo's Mining Heartland.” Africa Report 290.

Kilosho Buraye, Janvier, Nik Stoop, and Marijke Verpoorten. 2017. "Defusing the Social Minefield of Gold Sites in Kamituga, South Kivu. From Legal Pluralism to the ReMaking of Institutions?" Resources Policy 53 (September): 356-68.

La Libre Afrique. 2019. "RDC : Banro suspend ses opérations sur 3 sites miniers suite à l'insécurité." La Libre Afrique. September 26, 2019.

Laudati, Ann. 2013. "Beyond Minerals: Broadening 'Economies of Violence' in Eastern DRC." Review of African Political Economy 40 (135): 32-50.

Lichbach, Mark Irving. 1989. "An Evaluation of 'Does Economic Inequality Breed Political Conflict?' Studies.” World Politics 41 (4): 431-70.

1995. The Rebel's Dilemma. University of Michigan Press.

MacCulloch, Robert. 2004. "The Impact of Income on the Taste for Revolt." American Journal of Political Science 48 (4): 830-48.

Manski, Charles F. 1993. "Identification of Endogenous Social Effects: The Reflection Problem." The Review of Economic Studies 60 (3): 531-42.

Matthysen, Ken, Steven Spittaels, and Peer Schouten. 2019. "Mapping Artisanal Mining Areas and Mineral Supply Chains in Eastern DRC." IPIS.

Maystadt, Jean-François, Giacomo De Luca, Petros G. Sekeris, and John Ulimwengu. 2014. "Mineral Resources and Conflicts in DRC: A Case of Ecological Fallacy?" Oxford Economic Papers 66: 721-49. 
Mining Review Africa. 2017. "Banro Reports Violent Attack near Its Namoya Mine Site in the DRC." Mining Review Africa. May 19, 2017.

Muller, Edward N., Henry A. Dietz, and Steven E. Finkel. 1991. "Discontent and the Expected Utility of Rebellion: The Case of Peru." American Political Science Review 85 (4): 1261-82.

Muller, Edward N., and Karl-Dieter Opp. 1986. "Rational Choice and Rebellious Collective Action." The American Political Science Review 80 (2): 471-88.

Nussio, Enzo. 2017. "The Role of Sensation Seeking in Violent Armed Group Participation." Terrorism and Political Violence 0 (0): 1-19.

Olson, Mancur. 1965. The Logic of Collective Action. Harvard University Press.

Oster, Emily. 2019. "Unobservable Selection and Coefficient Stability: Theory and

Evidence." Journal of Business \& Economic Statistics 37 (2): 187-204.

Parker, Dominic P., Jeremy D. Foltz, and David Elsea. 2016. "Unintended Consequences of Sanctions for Human Rights: Conflict Minerals and Infant Mortality." The Journal of Law and Economics 59 (4): 731-74.

Parker, Dominic P., and Bryan Vadheim. 2017. "Resource Cursed or Policy Cursed? US Regulation of Conflict Minerals and Violence in the Congo." Journal of the Association of Environmental and Resource Economists 4 (1): 1-49.

Puijenbroeck, J van, and P. Schouten. 2013. "Le 6ième Chantier? L'économie Politique de L'exploitation Auifière Artisanale et Le Sous-Développement En Ituri." L'Afrique Des Grands Lacs. Annuaire 2012-2013.

Radio Okapi. 2019a. "Maniema : la société civile appelle la BANRO à respecter l'accord signé avec la notabilité de Salamabila." Radio Okapi. September 25, 2019.

. 2019b. "RDC : la société canadienne BANRO suspend ses activités dans le Maniema." Radio Okapi. September 29, 2019.

Radley, Ben. 2019. "Mining Industrialisation in the African Periphery: Disruption and Dependency in South Kivu, DRC." CERES, Research School for Resource Studies for Development.

Ross, Aaron. 2017. "Militia Violence Shutters Banro Gold Mine in East Congo." Reuters, July 3, 2017.

Sanchez de la Sierra, Raul. 2019. "On the Origins of the State: Stationary Bandits and Taxation in Eastern Congo." Journal of Political Economy, April.

Stearns, Jason, and Christoph Vogel. 2015. "The Landscape of Armed Groups in the Eastern Congo." Congo Research Group, Center on International Cooperation.

Stoop, Nik, Marijke Verpoorten, and Peter van der Windt. 2018. "More Legislation, More Violence? The Impact of Dodd-Frank in the DRC." PLOS ONE 13 (8): e0201783. 2019. "Artisanal or Industrial Conflict Minerals? Evidence from Eastern Congo." World Development 122 (October): 660-74.

Thyne, Clayton L., and Ryan D. Schroeder. 2012. "Social Constraints and Civil War: Bridging the Gap with Criminological Theory." The Journal of Politics 74 (4): 106678.

Tullock, Gordon. 1971. “The Paradox of Revolution.” Public Choice 11: 89-99.

UN. 2010. "Letter Dated 15 November 2010 from the Chair of the Security Council Committee Concerning the DRC" S/2010/596. United Nations.

Verweijen, Judith. 2017. "Luddites in the Congo?" City 21 (3-4): 466-82.

Vlassenroot, Koen, and Timothy Raeymaekers. 2004. Conflict and Social Transformation in Eastern DR Congo. Gent: Academia Press Scientific Publishers.

Vogel, Christoph, and Josaphat Musamba. 2016. "Recyclage De Rebelles? La Démobilisation Au Congo.” Rift Valley Institute. 
Voors, Maarten J., Eleonora E.M. Nillesen, Philip Verwimp, Erwin H. Bulte, Robert Lensink, and Daan P. Van Soest. 2012. "Violent Conflict and Behavior: A Field Experiment in Burundi." The American Economic Review 102 (2): 941-64.

Weyns, Yannick, Lotte Hoex, and Ken Matthysen. 2016. "Analysis of the Interactive Map of Artisanal Mining Areas in Eastern DRC. 2015 Update.” Antwerp: IPIS.

World Bank. 2008. "DRC - Growth with Governance in the Mining Sector." 43402-ZR. World Bank.

. 2009. "Mining Together. Large-Scale Mining Meets Artisanal Mining: A Guide for Action." Communities and Small-scale Mining. 


\section{FIGURES}

PANEL A: LSM CONCESSIONS AND AEZ

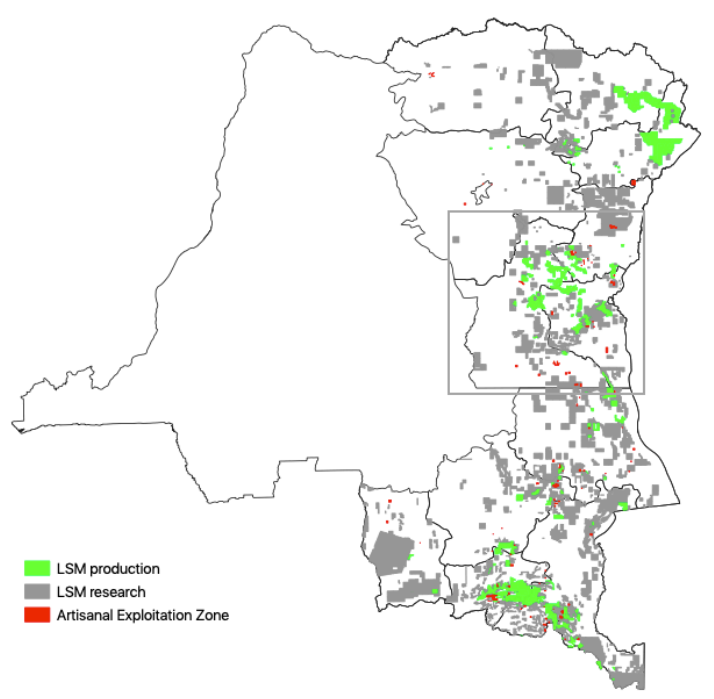

PANEL B: ARTISANAL MINING SITES

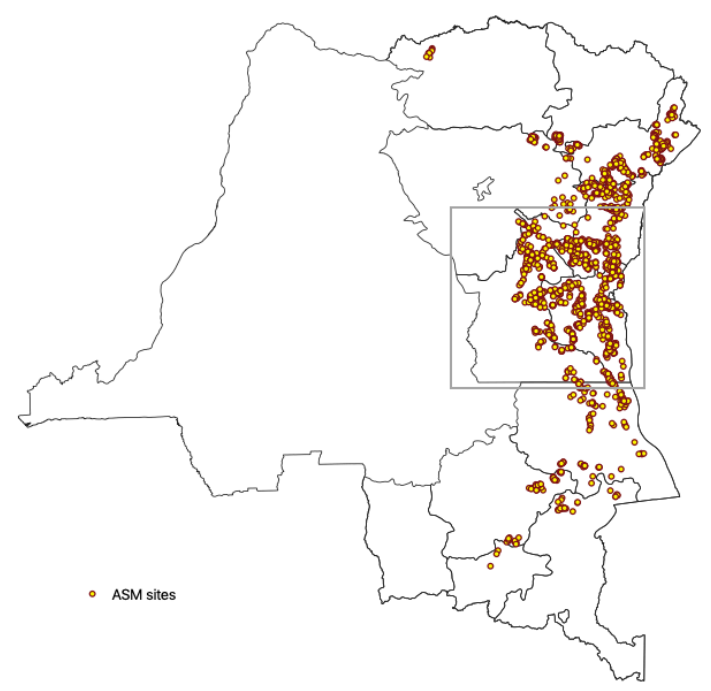

PANEL C: LSM CONCESSIONS BANRO

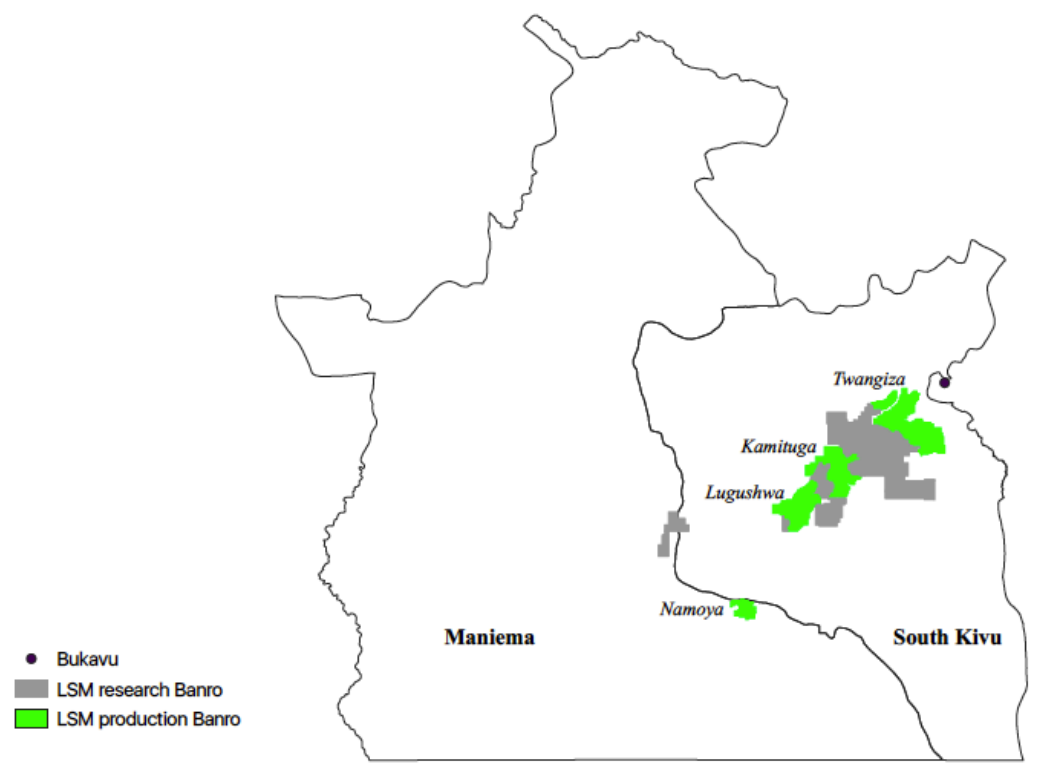

FIGURE 1. MINING IN EASTERN DRC

Notes: Panel A shows the location of LSM concessions and AEZ registered by the Congolese Mining Cadaster. Panel B shows the location of ASM sites registered by the International Peace Information Service. The square in Panels $\mathrm{A}$ and $\mathrm{B}$ covers the provinces of Maniema and South-Kivu. Panel C shows the location of Banro's research and production concessions in these provinces. All maps reflect the situation in 2015. 
PANEL A: HOW LIKELY IS IT THAT YOU WOULD ...
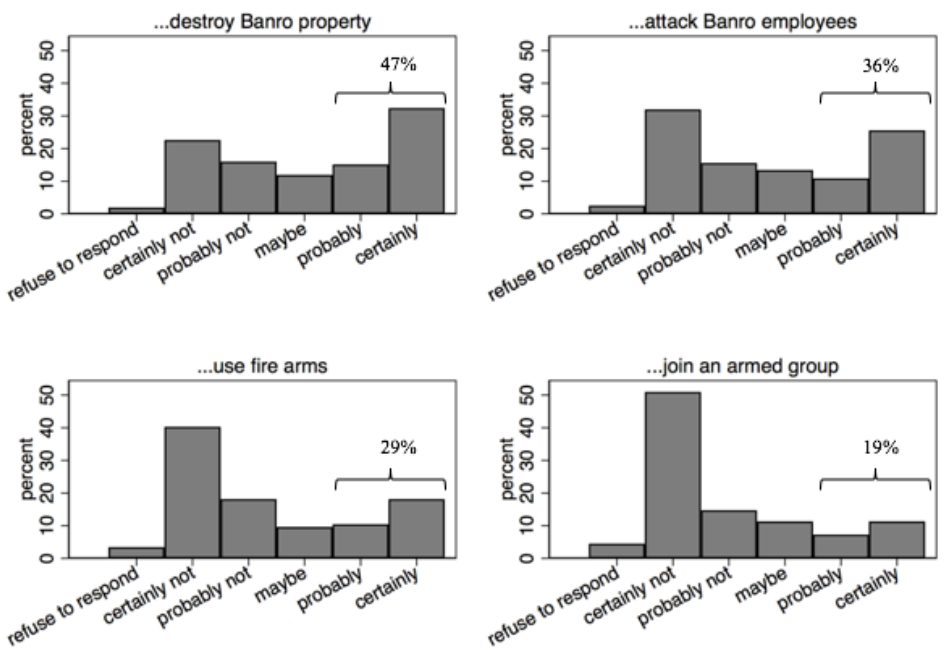

PANEL B: PROXIES FOR THE INTENTION TO FIGHT
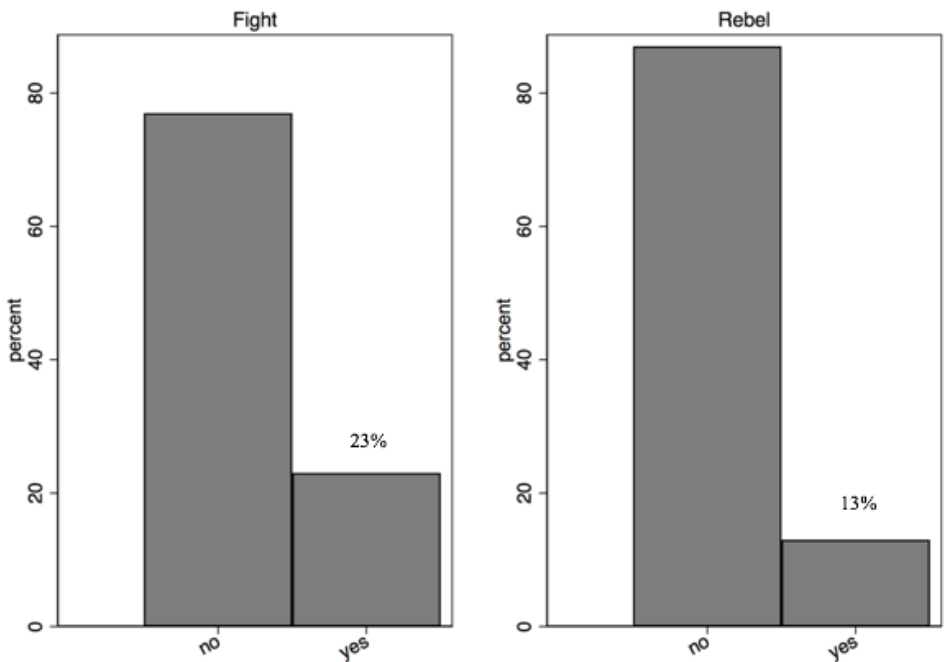

FIGURE 2. INTENTION TO FIGHT

Notes: Panel A displays miners' individual intention to engage in four violent actions should they have to leave the artisanal mining site. Panel B displays our proxies for the intention to fight. The first proxy equals one for miners that display a 'probable' or 'certain' intention to destroy Banro property, attack Banro employees and use fire arms. The second proxy equals one for miners that additionally display a 'probable' or 'certain' intention to join an armed group. 

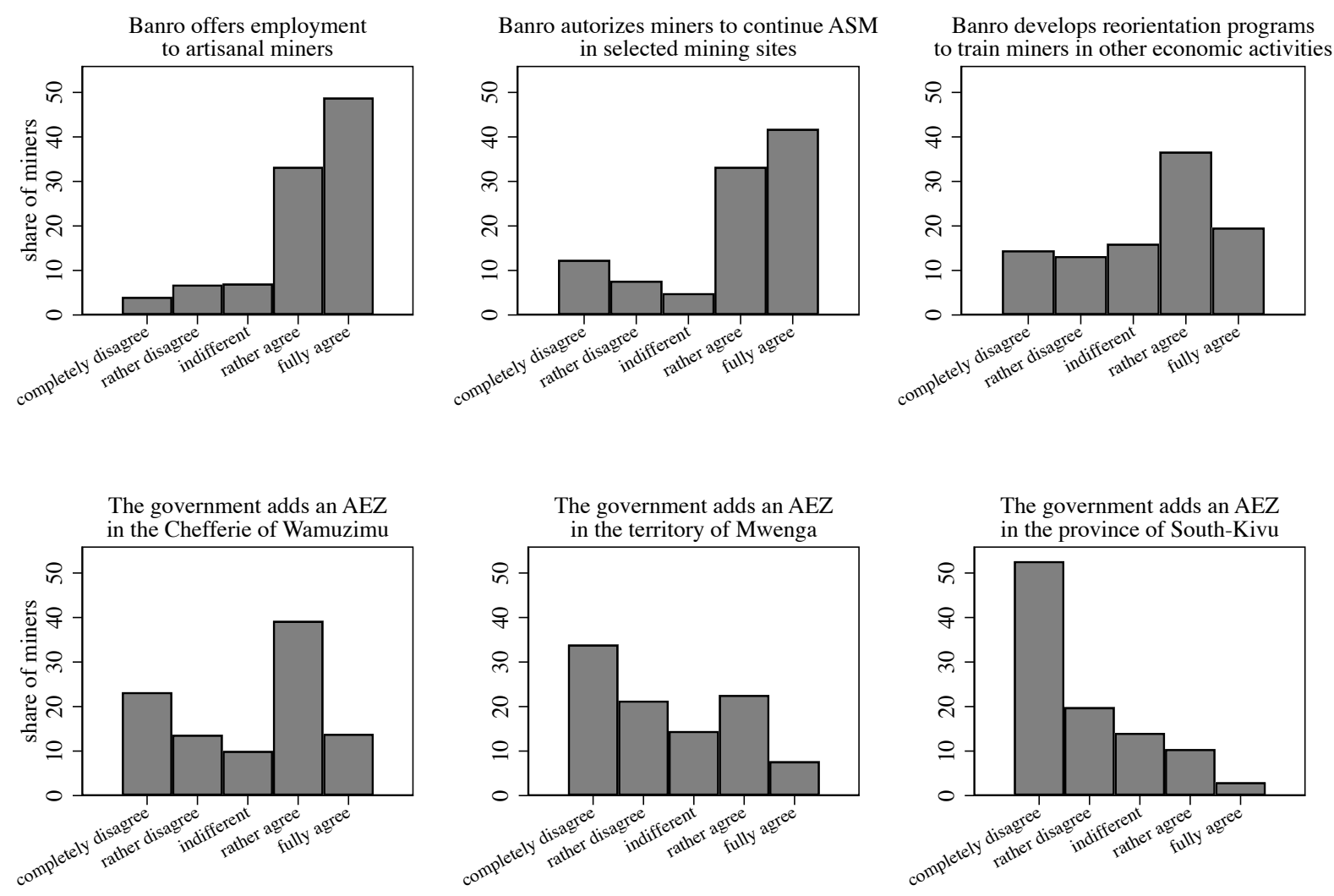

FIGURE 3. POLICY MEASURES TO PRESERVE SOCIAL PEACE

Notes: We presented miners with six policy measures and asked to what degree they agreed these would help avoid conflict with Banro. Kamituga is located in the Chefferie of Wamuzimu, part of the larger territory of Mwenga in the province of South-Kivu. 


\section{TABLES}

TABLE 1 -SUMMARY STATISTICS

\begin{tabular}{|c|c|c|c|c|c|}
\hline & Obs. & Mean & Std. Dev. & Min. & Max. \\
\hline destroy Banro property & 469 & 0.48 & 0.50 & 0 & 1 \\
\hline attack Banro employees & 469 & 0.36 & 0.48 & 0 & 1 \\
\hline use fire arms & 469 & 0.29 & 0.45 & 0 & 1 \\
\hline join an armed group & 469 & 0.19 & 0.39 & 0 & 1 \\
\hline fight & 469 & 0.23 & 0.42 & 0 & 1 \\
\hline rebel & 469 & 0.13 & 0.34 & 0 & 1 \\
\hline rebel in pit & 469 & 0.29 & 0.46 & 0 & 1 \\
\hline performed forced labor under armed threat & 469 & 0.41 & 0.49 & 0 & 1 \\
\hline forced to give away revenue/goods under armed threat & 469 & 0.29 & 0.45 & 0 & 1 \\
\hline house was destroyed or pillaged by armed groups & 469 & 0.28 & 0.45 & 0 & 1 \\
\hline displaced due to armed combat & 469 & 0.78 & 0.41 & 0 & 1 \\
\hline physically hurt during armed combat & 469 & 0.05 & 0.21 & 0 & 1 \\
\hline close family physically hurt during armed combat & 469 & 0.24 & 0.43 & 0 & 1 \\
\hline relatives physically hurt during armed combat & 469 & 0.40 & 0.49 & 0 & 1 \\
\hline witnessed killing or rape & 469 & 0.29 & 0.46 & 0 & 1 \\
\hline impact Mai-Mai Shikito & 469 & 0.14 & 0.35 & 0 & 1 \\
\hline opinion Banro CSR & 469 & 0.18 & 0.38 & 0 & 1 \\
\hline interested in working for Banro & 469 & 0.55 & 0.50 & 0 & 1 \\
\hline frequency Banro visits & 469 & 2.89 & 4.55 & 0 & 31 \\
\hline willingness to relocate & 469 & 0.52 & 0.50 & 0 & 1 \\
\hline willingness to reorient & 469 & 13.67 & 8.08 & 1 & 30 \\
\hline opinion local mediating institutions & 469 & 3.17 & 0.92 & 1 & 5 \\
\hline opinion Banro security forces & 469 & 2.67 & 0.95 & 1 & 5 \\
\hline pit manager & 469 & 0.08 & 0.28 & 0 & 1 \\
\hline asset quintiles & 469 & 2.97 & 1.41 & 1 & 5 \\
\hline finished high school & 469 & 0.19 & 0.39 & 0 & 1 \\
\hline number of $\mathrm{HH}$ income sources & 469 & 1.54 & 0.65 & 1 & 3 \\
\hline born in Kamituga & 469 & 0.52 & 0.50 & 0 & 1 \\
\hline has child $<10$ years & 469 & 0.70 & 0.46 & 0 & 1 \\
\hline age & 469 & 33.26 & 10.09 & 16 & 65 \\
\hline single & 469 & 0.21 & 0.41 & 0 & 1 \\
\hline
\end{tabular}

Notes: Asset quintiles were created based on scores from a principal component analysis considering various household assets (i.e. quality of the walls and floor in which the household resides, as well as the number of houses, rooms, mattresses, TV's and radios owned by the household). 


\begin{tabular}{|c|c|c|c|c|}
\hline & \multicolumn{2}{|c|}{ Fight } & \multicolumn{2}{|c|}{ Rebel } \\
\hline & (1) & (2) & (3) & (4) \\
\hline \multirow[t]{2}{*}{ rebel in pit } & $0.137^{* \star *}$ & $0.119^{* * \star}$ & $0.122^{\star \star \star}$ & $0.122^{* \star \star}$ \\
\hline & $(0.037)$ & $(0.040)$ & $(0.028)$ & $(0.040)$ \\
\hline \multirow[t]{2}{*}{ witnessed killing or rape } & $0.106^{\star \star \star}$ & $0.106^{\star *}$ & $0.080^{\star \star \star}$ & $0.082^{\star \star \star}$ \\
\hline & $(0.038)$ & $(0.046)$ & $(0.029)$ & $(0.032)$ \\
\hline \multirow[t]{2}{*}{ impact Mai-Mai Shikito } & $0.093^{*}$ & 0.086 & $0.087^{\star \star}$ & 0.082 \\
\hline & $(0.054)$ & $(0.053)$ & $(0.043)$ & $(0.050)$ \\
\hline \multirow[t]{2}{*}{ opinion Banro CSR } & $-0.101^{*}$ & $-0.098^{\star \star \star}$ & $-0.116^{* *}$ & $-0.123^{\star \star \star}$ \\
\hline & $(0.056)$ & $(0.038)$ & $(0.053)$ & $(0.035)$ \\
\hline \multirow[t]{2}{*}{ interested in working for Banro } & $-0.080^{* *}$ & -0.090 & $-0.049^{*}$ & $-0.060^{\star \star}$ \\
\hline & $(0.037)$ & $(0.058)$ & $(0.029)$ & $(0.030)$ \\
\hline \multirow[t]{2}{*}{ frequency Banro visits } & $0.008^{* *}$ & $0.007^{\star \star \star}$ & $0.009^{\star \star \star}$ & $0.008^{* \star *}$ \\
\hline & $(0.004)$ & $(0.003)$ & $(0.003)$ & $(0.002)$ \\
\hline \multirow[t]{2}{*}{ willingness to relocate } & 0.030 & 0.028 & -0.002 & -0.007 \\
\hline & $(0.038)$ & $(0.036)$ & $(0.030)$ & $(0.020)$ \\
\hline \multirow[t]{2}{*}{ willingness to reorient } & 0.002 & 0.002 & 0.003 & 0.002 \\
\hline & $(0.002)$ & $(0.003)$ & $(0.002)$ & $(0.002)$ \\
\hline \multirow[t]{2}{*}{ opinion local mediating institutions } & -0.038 & -0.029 & $-0.039^{* *}$ & $-0.032^{*}$ \\
\hline & $(0.025)$ & $(0.028)$ & $(0.019)$ & $(0.018)$ \\
\hline \multirow[t]{2}{*}{ opinion Banro security forces } & $0.070^{* \star *}$ & $0.069^{\star *}$ & $0.032^{*}$ & $0.034^{* *}$ \\
\hline & $(0.024)$ & $(0.027)$ & $(0.019)$ & $(0.017)$ \\
\hline \multirow[t]{2}{*}{ pit manager } & -0.008 & 0.006 & 0.059 & 0.056 \\
\hline & $(0.073)$ & $(0.046)$ & $(0.054)$ & $(0.042)$ \\
\hline \multirow[t]{2}{*}{ asset quintile 2} & -0.072 & -0.064 & -0.061 & $-0.065^{*}$ \\
\hline & $(0.058)$ & $(0.043)$ & $(0.044)$ & $(0.035)$ \\
\hline \multirow[t]{2}{*}{ asset quintile 3} & -0.050 & $-0.047^{\star}$ & -0.045 & $-0.048^{*}$ \\
\hline & $(0.059)$ & $(0.029)$ & $(0.045)$ & $(0.026)$ \\
\hline \multirow[t]{2}{*}{ asset quintile 4} & 0.011 & 0.010 & -0.037 & -0.040 \\
\hline & $(0.056)$ & $(0.022)$ & $(0.043)$ & $(0.027)$ \\
\hline \multirow[t]{2}{*}{ asset quintile 5} & 0.040 & 0.037 & -0.047 & $-0.049^{*}$ \\
\hline & $(0.062)$ & $(0.026)$ & $(0.049)$ & $(0.026)$ \\
\hline \multirow[t]{2}{*}{ finished high school } & $-0.085^{*}$ & -0.086 & -0.055 & -0.052 \\
\hline & $(0.049)$ & $(0.055)$ & $(0.040)$ & $(0.034)$ \\
\hline \multirow[t]{2}{*}{ number of $\mathrm{HH}$ income sources } & $-0.051^{*}$ & $-0.049^{*}$ & $-0.052^{* *}$ & $-0.052^{* \star}$ \\
\hline & $(0.030)$ & $(0.028)$ & $(0.024)$ & $(0.025)$ \\
\hline \multirow[t]{2}{*}{ born in Kamituga } & 0.038 & 0.029 & 0.041 & 0.039 \\
\hline & $(0.037)$ & $(0.059)$ & $(0.029)$ & $(0.050)$ \\
\hline \multirow[t]{2}{*}{ has child $<10$ years } & -0.058 & -0.066 & -0.061 & $-0.068^{* \star}$ \\
\hline & $(0.054)$ & $(0.052)$ & $(0.043)$ & $(0.031)$ \\
\hline \multirow[t]{2}{*}{ age } & $-0.004^{*}$ & $-0.005^{\star}$ & $-0.003^{*}$ & $-0.003^{*}$ \\
\hline & $(0.002)$ & $(0.002)$ & $(0.002)$ & $(0.002)$ \\
\hline \multirow[t]{2}{*}{ single } & -0.018 & -0.022 & -0.020 & -0.029 \\
\hline & $(0.065)$ & $(0.066)$ & $(0.051)$ & $(0.049)$ \\
\hline Observations & 469 & 469 & 469 & 469 \\
\hline Zone FE & no & yes & no & yes \\
\hline Clustered s.e. & no & yes & no & yes \\
\hline Pseudo $\mathrm{R}^{2}$ & 0.16 & 0.18 & 0.22 & 0.26 \\
\hline
\end{tabular}




\section{Appendix 1: Selection on unobservables}

Given the lack of exogenous variation, the main findings presented in Section V.A. of the paper merely provide evidence of correlations, not of causal relations. The main difficulty to infer causation lies with miners' unobserved characteristics that may influence both the explanatory and dependent variables, thus causing spurious correlation. This issue is particularly relevant in the case of previous conflict exposure and having a rebel network. Conflict exposure only partly relates to random bad luck, and partly to unobserved war-time decisions and behavior of our respondents. Moreover, miners with a larger rebel network may be more likely to have participated in the activities of an armed group themselves, even if they report otherwise. Past participation, except in the case of forced recruitment, clearly is a decision variable and thus prone to endogeneity.

To formally assess omitted variable bias, we turn to the approach proposed by Altonji et al. (2005) and fine-tuned by Oster (2019). It uses the selection on observable variables as a guide to assess the potential bias from unobserved variables. Selection on observable variables can be evaluated by looking at coefficient movements in the estimates of conflict exposure and rebel networks while gradually adding additional control variables; their relevance is assessed by the associated movements in the R-squared. Based on these insights, Oster (2019) developed a measure that indicates how large selection on unobservable variables has to be, relative to selection on observables, to fully explain away the estimated effect. ${ }^{1}$

The larger the measure, denoted by $\delta$, the less likely the threat of omitted variable bias. To calculate $\delta$, we first run two regressions for each outcome variable: an uncontrolled and a controlled regression. In the uncontrolled regression, we only regress the outcome variable on past victimization or rebel networks. In the controlled regression we control for the remaining

\footnotetext{
${ }^{1}$ The calculations can be performed with the Stata Code 'psacalc', provided by Oster (2019) and freely available through Stata's ssc.
} 
observed covariates. Denote the estimated coefficient on past victimization or rebel networks $\beta^{u}$ in the uncontrolled regression and $\beta^{c}$ in the controlled regression; $R^{u}$ and $R^{c}$ are the Rsquared values associated with these regressions. Next, the procedure requires making an assumption about $R_{\max }$, which is defined as the R-squared from a hypothetical regression that controls for all observed and unobserved covariates. We follow Oster (2019) in setting $\bar{R}_{\text {max }}=$ $1.3 R^{c} \cdot 2 \delta$ is then calculated as follows: $\delta=\frac{\beta^{c}\left(R^{c}-R^{u}\right)}{\left(\beta^{u}-\beta^{c}\right)\left(\bar{R}_{\max }-R^{c}\right)} \cdot{ }^{3}$ Oster (2019) argues that a value of $\delta>1$ (i.e. that selection on observables is at least as important as selection on unobservables) indicates a result that is robust to omitted variable bias.

We calculated $\delta$ for our measures of having a rebel network (working in a pit with a rebel) and previous exposure to conflict (having witnessed killing or rape). Table A.1 presents the results. In all cases we find that $\delta>1$. For having a rebel network, we find that selection on unobserved covariates has to be 3 to 5 times as important as selection on the included variables to fully explain away the estimates presented in Table 2 of the paper. For having witnessed killing or rape, we find larger values of $\delta$, indicating that selection on unobserved covariates would have to be between 9 and 13 times as important as selection on included covariates. These results suggest that our findings are not sensitive to omitted variable bias.

\footnotetext{
${ }^{2}$ Oster (2019) derives this value by analysing coefficient movements in 65 results from randomized studies published in five top economic journals (American Economic Review, Quarterly Journal of Economics, The Journal of Political Economy, Econometrica and American Economic Journal - Applied Economics) between 2008-2013. The argument is that one can use the stability of randomized data to infer what stability we might expect from non-randomized data when the treatment is exogenous. With a value of $R_{\max }=1.3 R^{c}, 90 \%$ of the evaluated randomized results survived the $\delta=1$ cutoff. In contrast, this was only the case for $45 \%$ of results from non-randomized studies published in the same journals and time range.

${ }^{3}$ Consider the intuition behind this expression. We find $\beta^{c}$ in the numerator, indicating that the larger $\beta^{c}$, the larger the effect that needs to be explained away by selection on unobservables. In the denominator we find $\left(\beta^{u}-\right.$ $\beta^{c}$ ): the smaller the difference between $\beta^{u}$ and $\beta^{c}$, the less the estimate is affected by selection on observables, and the larger selection on unobservables needs to be, relative to selection on observables, to fully explain away the estimated effect. The strength of the observed covariates increases in $\left(R^{c}-R^{u}\right)$ and decreases in $\left(\bar{R}_{\max }-\right.$ $R^{c}$ ): the larger the difference between $R^{c}$ and $R^{u}$, the more variation in the outcome variable is accounted for by observed covariates; on the other hand, the smaller the difference between $\bar{R}_{\max }$ and $R^{c}$, the more of the "explainable" variation is accounted for by the observed covariates.
} 


\begin{tabular}{lcccc} 
& \multicolumn{2}{c}{ rebel in pit } & \multicolumn{2}{c}{ witnessed killing or rape } \\
& $\delta$ & $\bar{R}_{\max }$ & $\delta$ & $\bar{R}_{\max }$ \\
\hline Fight & 3.39 & 0.25 & 13.4 & 0.25 \\
Rebel & 4.64 & 0.25 & 8.64 & 0.25 \\
\hline
\end{tabular}

Notes: $\delta$ is a measure that indicates how large selection on unobservables needs to be, relative to selection on observables, to fully explain away the estimated effects for rebel networks and exposure to conflict in Table 2 of the paper. As suggested by Oster (2019), we set $\overline{\mathrm{R}}_{\max }=1.3 \mathrm{R}^{\mathrm{c}}$. 


\section{Appendix 2: Robustness Checks}

TABLe A.2-Intention to Fight

\begin{tabular}{|c|c|c|c|c|c|}
\hline & \multicolumn{5}{|c|}{ Fight } \\
\hline & (1) & $(2)$ & $(3)$ & (4) & $(5)$ \\
\hline \multirow[t]{2}{*}{ rebel in pit } & $0.124^{\star \star \star}$ & $0.135^{\star \star \star}$ & & & $0.119^{\star \star \star}$ \\
\hline & $(0.026)$ & $(0.033)$ & & & $(0.040)$ \\
\hline \multirow[t]{2}{*}{ witnessed killing or rape } & $0.089^{\star}$ & $0.103^{\star \star}$ & & & $0.106^{\star \star}$ \\
\hline & $(0.049)$ & $(0.043)$ & & & $(0.046)$ \\
\hline \multirow[t]{2}{*}{ impact Mai-Mai Shikito } & $0.119^{\star}$ & $0.141^{\star \star}$ & & & 0.086 \\
\hline & $(0.068)$ & $(0.065)$ & & & $(0.053)$ \\
\hline \multirow[t]{2}{*}{ opinion Banro CSR } & & & $-0.094^{\star \star}$ & $-0.099^{\star \star \star}$ & $-0.098^{\star \star \star}$ \\
\hline & & & $(0.042)$ & $(0.035)$ & $(0.038)$ \\
\hline \multirow[t]{2}{*}{ interested in working for Banro } & & & -0.095 & -0.080 & -0.090 \\
\hline & & & $(0.062)$ & $(0.059)$ & $(0.058)$ \\
\hline \multirow[t]{2}{*}{ frequency Banro visits } & & & $0.007^{\star \star \star}$ & $0.008^{\star \star \star}$ & $0.007^{\star \star \star}$ \\
\hline & & & $(0.002)$ & $(0.002)$ & $(0.003)$ \\
\hline \multirow[t]{2}{*}{ willingness to relocate } & & & $0.057^{\star}$ & 0.048 & 0.028 \\
\hline & & & $(0.034)$ & $(0.036)$ & $(0.036)$ \\
\hline \multirow[t]{2}{*}{ willingness to reorient } & & & 0.002 & 0.002 & 0.002 \\
\hline & & & $(0.003)$ & $(0.003)$ & $(0.003)$ \\
\hline \multirow[t]{2}{*}{ opinion local mediating institutions } & & & -0.033 & -0.032 & -0.029 \\
\hline & & & $(0.027)$ & $(0.029)$ & $(0.028)$ \\
\hline \multirow[t]{2}{*}{ opinion Banro security forces } & & & $0.083^{* \star *}$ & $0.081^{\star \star \star}$ & $0.069^{\star *}$ \\
\hline & & & $(0.027)$ & $(0.027)$ & $(0.027)$ \\
\hline \multirow[t]{2}{*}{ pit manager } & & 0.021 & & 0.008 & 0.006 \\
\hline & & $(0.065)$ & & $(0.043)$ & $(0.046)$ \\
\hline \multirow[t]{2}{*}{ asset quintile 2} & & -0.035 & & $-0.067^{\star}$ & -0.064 \\
\hline & & $(0.047)$ & & $(0.040)$ & $(0.043)$ \\
\hline \multirow[t]{2}{*}{ asset quintile 3} & & -0.030 & & $-0.063^{\star \star}$ & $-0.047^{*}$ \\
\hline & & $(0.030)$ & & $(0.030)$ & $(0.029)$ \\
\hline \multirow[t]{2}{*}{ asset quintile 4} & & $0.050^{\star *}$ & & 0.011 & 0.010 \\
\hline & & $(0.021)$ & & $(0.023)$ & $(0.022)$ \\
\hline \multirow[t]{2}{*}{ asset quintile 5} & & $0.062^{*}$ & & 0.025 & 0.037 \\
\hline & & $(0.037)$ & & $(0.033)$ & $(0.026)$ \\
\hline \multirow[t]{2}{*}{ finished high school } & & $-0.095^{\star}$ & & -0.078 & -0.086 \\
\hline & & $(0.057)$ & & $(0.054)$ & $(0.055)$ \\
\hline \multirow[t]{2}{*}{ number of $\mathrm{HH}$ income sources } & & $-0.074^{\star \star \star}$ & & -0.040 & $-0.049^{*}$ \\
\hline & & $(0.023)$ & & $(0.033)$ & $(0.028)$ \\
\hline \multirow[t]{2}{*}{ born in Kamituga } & & 0.028 & & 0.019 & 0.029 \\
\hline & & $(0.063)$ & & $(0.063)$ & $(0.059)$ \\
\hline \multirow[t]{2}{*}{ has child $<10$ years } & & -0.071 & & -0.061 & -0.066 \\
\hline & & $(0.051)$ & & $(0.056)$ & $(0.052)$ \\
\hline \multirow[t]{2}{*}{ age } & & $-0.004^{*}$ & & -0.003 & $-0.005^{\star}$ \\
\hline & & $(0.002)$ & & $(0.002)$ & $(0.002)$ \\
\hline \multirow[t]{2}{*}{ single } & & -0.017 & & -0.014 & -0.022 \\
\hline & & $(0.061)$ & & $(0.063)$ & $(0.066)$ \\
\hline Observations & 469 & 469 & 469 & 469 & 469 \\
\hline Zone FE & yes & yes & yes & yes & yes \\
\hline Clustered s.e. & yes & yes & yes & yes & yes \\
\hline Pseudo $\mathrm{R}^{2}$ & 0.07 & 0.12 & 0.11 & 0.14 & 0.18 \\
\hline
\end{tabular}

Notes: $* * * \mathrm{p}<0.01, * * \mathrm{p}<0.05, * \mathrm{p}<0.1$; the coefficients represent marginal effects calculated after a probit regression; standard errors are clustered at the level of the mining zone and reported between brackets. 


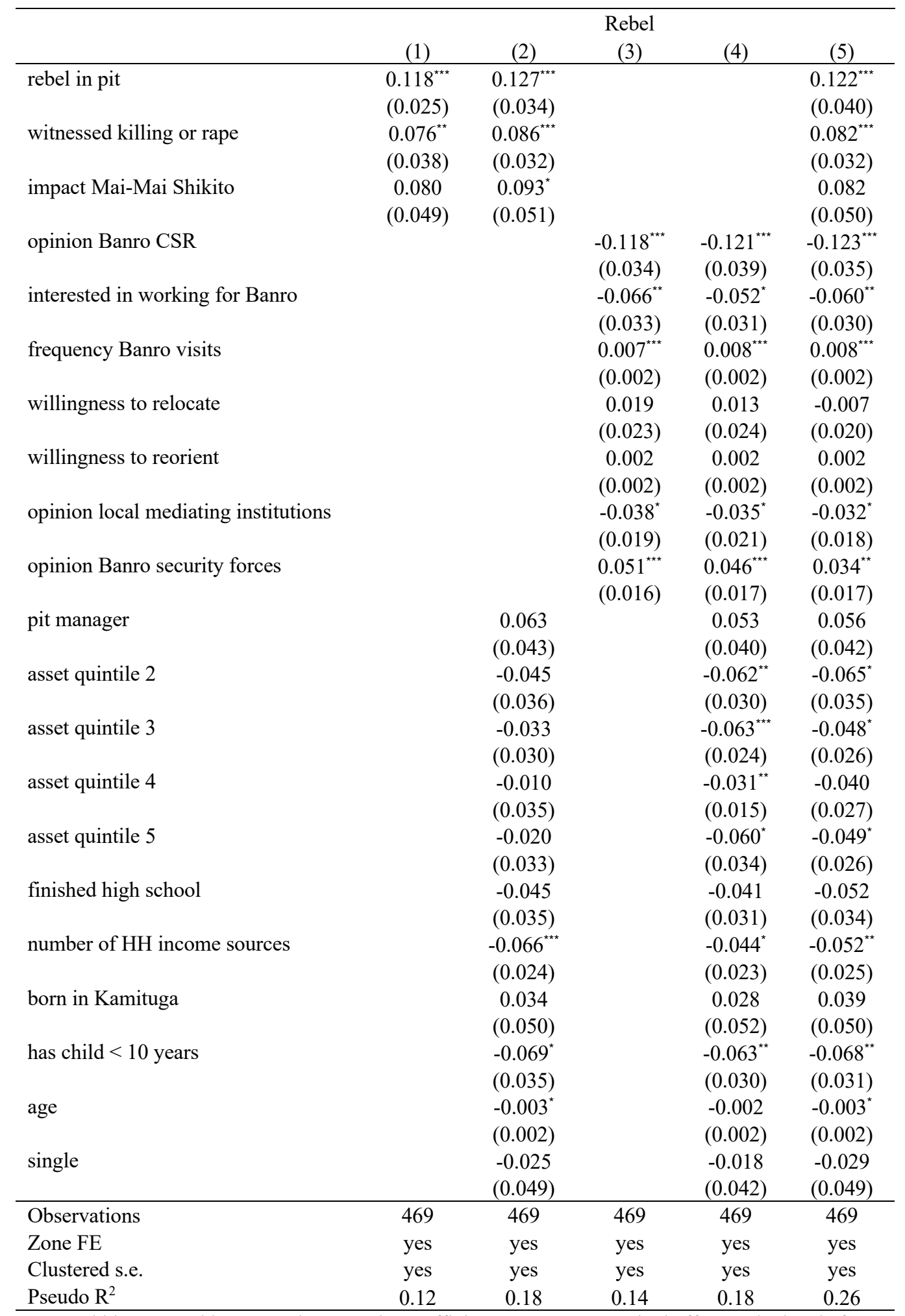

Notes: $* * * \mathrm{p}<0.01,{ }^{*} \mathrm{p}<0.05, * \mathrm{p}<0.1$; the coefficients represent marginal effects calculated after a probit regression; standard errors are clustered at the level of the mining zone and reported between brackets. 
TABLE A.4-WILD CLUSTER BOOTSTRAP

\begin{tabular}{|c|c|c|}
\hline & $\begin{array}{l}\text { Fight } \\
\text { (1) }\end{array}$ & $\begin{array}{l}\text { Rebel } \\
(2)\end{array}$ \\
\hline \multirow[t]{3}{*}{ rebel in pit } & $0.479^{* *}$ & $0.773^{* *}$ \\
\hline & $\{0.003\}$ & $\{0.003\}$ \\
\hline & {$[0.027]$} & {$[0.010]$} \\
\hline \multirow{3}{*}{ witnessed killing or rape } & $0.426^{*}$ & $0.523^{\text {*** }}$ \\
\hline & $\{0.028\}$ & $\{0.016\}$ \\
\hline & {$[0.061]$} & {$[0.026]$} \\
\hline \multirow[t]{3}{*}{ impact Mai-Mai Shikito } & 0.344 & 0.522 \\
\hline & $\{0.119\}$ & $\{0.124\}$ \\
\hline & {$[0.216]$} & {$[0.198]$} \\
\hline \multirow[t]{3}{*}{ opinion Banro CSR } & $-0.394^{* *}$ & $-0.783^{* * *}$ \\
\hline & $\{0.007\}$ & $\{0.002\}$ \\
\hline & {$[0.020]$} & {$[0.004]$} \\
\hline \multirow{3}{*}{ interested in working for Banro } & -0.362 & $-0.383^{*}$ \\
\hline & $\{0.129\}$ & $\{0.055\}$ \\
\hline & {$[0.173]$} & {$[0.086]$} \\
\hline \multirow[t]{3}{*}{ frequency Banro visits } & $0.030^{* *}$ & $0.048^{* * * *}$ \\
\hline & $\{0.006\}$ & $\{0.000\}$ \\
\hline & {$[0.023]$} & {$[0.005]$} \\
\hline \multirow[t]{3}{*}{ willingness to relocate } & 0.114 & -0.042 \\
\hline & $\{0.429\}$ & $\{0.741\}$ \\
\hline & {$[0.424]$} & {$[0.747]$} \\
\hline \multirow[t]{3}{*}{ willingness to reorient } & 0.008 & 0.016 \\
\hline & $\{0.425\}$ & $\{0.296\}$ \\
\hline & {$[0.445]$} & {$[0.335]$} \\
\hline \multirow[t]{3}{*}{ opinion local mediating institutions } & -0.118 & -0.205 \\
\hline & $\{0.293\}$ & $\{0.073\}$ \\
\hline & {$[0.394]$} & {$[0.225]$} \\
\hline \multirow{3}{*}{ opinion Banro security forces } & $0.278^{* * * *}$ & $0.218^{* * *}$ \\
\hline & $\{0.008\}$ & $\{0.031\}$ \\
\hline & {$[0.008]$} & {$[0.035]$} \\
\hline \multirow{3}{*}{ pit manager } & 0.024 & 0.353 \\
\hline & $\{0.895\}$ & $\{0.180\}$ \\
\hline & {$[0.898]$} & {$[0.284]$} \\
\hline \multirow[t]{3}{*}{ asset quintile 2} & -0.258 & -0.415 \\
\hline & $\{0.136\}$ & $\{0.063\}$ \\
\hline & {$[0.144]$} & {$[0.110]$} \\
\hline \multirow[t]{3}{*}{ asset quintile 3} & -0.190 & -0.305 \\
\hline & $\{0.091\}$ & $\{0.064\}$ \\
\hline & {$[0.149]$} & {$[0.113]$} \\
\hline asset quintile 4 & 0.042 & -0.257 \\
\hline & $\{0.635\}$ & $\{0.133\}$ \\
\hline & {$[0.652]$} & {$[0.243]$} \\
\hline asset quintile 5 & 0.149 & -0.310 \\
\hline & $\{0.155\}$ & $\{0.057\}$ \\
\hline & {$[0.200]$} & {$[0.138]$} \\
\hline finished high school & $-0.347^{*}$ & -0.331 \\
\hline & $\{0.129\}$ & $\{0.140\}$ \\
\hline & {$[0.098]$} & {$[0.147]$} \\
\hline number of $\mathrm{HH}$ income sources & -0.198 & $-0.328^{* *}$ \\
\hline & $\{0.073\}$ & $\{0.050\}$ \\
\hline & {$[0.134]$} & {$[0.023]$} \\
\hline born in Kamituga & 0.115 & 0.249 \\
\hline & $\{0.628\}$ & $\{0.434\}$ \\
\hline & {$[0.671]$} & [0.499] \\
\hline has child $<10$ years & -0.266 & $-0.429^{*}$ \\
\hline & $\{0.209\}$ & $\{0.041\}$ \\
\hline & {$[0.217]$} & {$[0.056]$} \\
\hline age & $-0.019^{*}$ & $-0.021^{*}$ \\
\hline & $\{0.058\}$ & $\{0.047\}$ \\
\hline & {$[0.079]$} & {$[0.064]$} \\
\hline single & -0.087 & -0.186 \\
\hline & $\{0.744\}$ & $\{0.548\}$ \\
\hline & {$[0.729]$} & {$[0.556]$} \\
\hline Observations & 469 & 469 \\
\hline Zone FE & yes & yes \\
\hline Clustered s.e. & yes & yes \\
\hline Pseudo $\mathrm{R}^{2}$ & 0.18 & 0.26 \\
\hline $\begin{array}{l}\text { Notes: The coefficients are estimate } \\
\text { probit model with standard errors cl } \\
\text { and bootstrap p-values from the dist } \\
\text { clustering for mining zones are repo } \\
\mathrm{p}<0.01,{ }^{* *} \mathrm{p}<0.05,{ }^{*} \mathrm{p}<0.1 \text { and is } \mathrm{b}\end{array}$ & $\begin{array}{l}\text { model; } p \\
\text { nining zo } \\
\text { wild boo } \\
\text { s. Signific }\end{array}$ & $\begin{array}{l}\text { conventi } \\
\text { ted in bra } \\
\text { after } \\
\text { by } * * *\end{array}$ \\
\hline
\end{tabular}




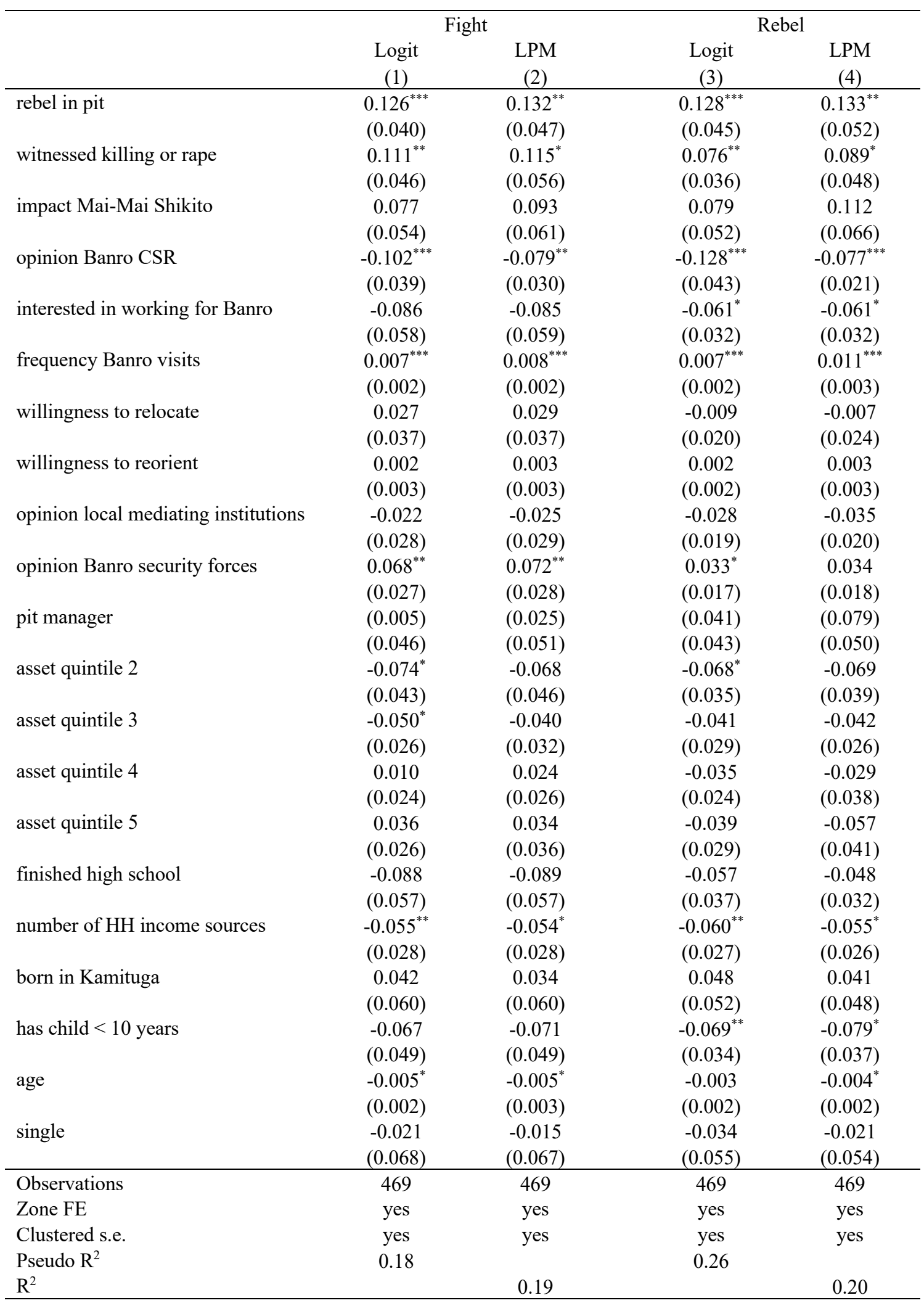

Notes: $* * * \mathrm{p}<0.01, * * \mathrm{p}<0.05, * \mathrm{p}<0.1$; Columns 1 and 3 present marginal effects calculated after a logit regression; Columns 2 and 4 present estimated coefficients from a Linear Probability Model; standard errors are reported between brackets, and clustered at the level of the mining zone. 


\begin{tabular}{lcc} 
& Fight & Rebel \\
\hline performed forced labor under armed threat & -0.045 & 0.013 \\
& $(0.031)$ & $(0.037)$ \\
forced to give away revenue/goods under armed threat & $0.068^{* * *}$ & $0.065^{* *}$ \\
house was destroyed or pillaged by armed groups & $(0.023)$ & $(0.026)$ \\
& -0.090 & -0.005 \\
displaced due to armed combat & $(0.063)$ & $(0.037)$ \\
& -0.033 & -0.031 \\
physically hurt during armed combat & $(0.054)$ & $(0.022)$ \\
& 0.084 & $0.100^{* *}$ \\
close family physically hurt during armed combat & $(0.065)$ & $(0.047)$ \\
& -0.005 & -0.015 \\
relatives physically hurt during armed combat & $(0.034)$ & $(0.026)$ \\
& -0.012 & -0.031 \\
witnessed killings or rape & $(0.027)$ & $(0.028)$ \\
& $0.106^{* *}$ & $0.082^{* * *}$ \\
Observations & $(0.046)$ & $(0.032)$ \\
Zone FE & 469 & 469 \\
Clustered s.e. & Yes & Yes \\
\hline
\end{tabular}

Notes: ${ }^{* * *} \mathrm{p}<0.01,{ }^{* *} \mathrm{p}<0.05,{ }^{*} \mathrm{p}<0.1$; the coefficients represent marginal effects calculated after running eight probit regressions, each time including a different indicator for conflict exposure; standard errors are reported between brackets, and clustered at the level of the mining zone. 


\begin{tabular}{|c|c|c|}
\hline & $\begin{array}{c}\text { Fight } \\
\text { (1) }\end{array}$ & $\begin{array}{c}\text { Rebel } \\
(2)\end{array}$ \\
\hline \multirow[t]{2}{*}{ rebel in pit } & $0.121^{\star \star \star}$ & $0.127^{\star \star \star}$ \\
\hline & $(0.046)$ & $(0.045)$ \\
\hline \multirow[t]{2}{*}{ witnessed killing or rape } & $0.100^{\star *}$ & $0.082^{\star \star \star}$ \\
\hline & $(0.042)$ & $(0.031)$ \\
\hline \multirow[t]{2}{*}{ impact Mai-Mai Shikito } & 0.078 & 0.069 \\
\hline & $(0.051)$ & $(0.049)$ \\
\hline \multirow[t]{2}{*}{ opinion Banro CSR } & $-0.086^{* *}$ & $-0.117^{\star \star \star}$ \\
\hline & $(0.034)$ & $(0.035)$ \\
\hline \multirow[t]{2}{*}{ interested in working for Banro } & -0.090 & $-0.057^{*}$ \\
\hline & $(0.064)$ & $(0.034)$ \\
\hline \multirow[t]{2}{*}{ frequency Banro visits } & $0.007^{\star \star \star}$ & $0.007^{\star \star \star}$ \\
\hline & $(0.003)$ & $(0.002)$ \\
\hline \multirow[t]{2}{*}{ willingness to relocate } & 0.029 & -0.004 \\
\hline & $(0.038)$ & $(0.020)$ \\
\hline \multirow[t]{2}{*}{ willingness to reorient } & 0.002 & 0.003 \\
\hline & $(0.002)$ & $(0.002)$ \\
\hline \multirow[t]{2}{*}{ opinion local mediating institutions } & -0.027 & $-0.031^{*}$ \\
\hline & $(0.027)$ & $(0.017)$ \\
\hline \multirow[t]{2}{*}{ opinion Banro security forces } & $0.070^{\star \star}$ & $0.032^{\star}$ \\
\hline & $(0.030)$ & $(0.019)$ \\
\hline \multirow[t]{2}{*}{ pit manager } & 0.001 & 0.052 \\
\hline & $(0.051)$ & $(0.046)$ \\
\hline \multirow[t]{2}{*}{ asset quintile 2} & -0.057 & $-0.063^{*}$ \\
\hline & $(0.044)$ & $(0.037)$ \\
\hline \multirow[t]{2}{*}{ asset quintile 3} & -0.056 & -0.046 \\
\hline & $(0.036)$ & $(0.028)$ \\
\hline \multirow[t]{2}{*}{ asset quintile 4} & 0.016 & -0.038 \\
\hline & $(0.021)$ & $(0.030)$ \\
\hline \multirow[t]{2}{*}{ asset quintile 5} & $0.048^{\star \star}$ & $-0.042^{*}$ \\
\hline & $(0.021)$ & $(0.024)$ \\
\hline \multirow[t]{2}{*}{ finished high school } & -0.078 & -0.045 \\
\hline & $(0.054)$ & $(0.033)$ \\
\hline \multirow[t]{2}{*}{ number of $\mathrm{HH}$ income sources } & -0.047 & $-0.046^{*}$ \\
\hline & $(0.032)$ & $(0.026)$ \\
\hline \multirow[t]{2}{*}{ born in Kamituga } & 0.022 & 0.038 \\
\hline & $(0.059)$ & $(0.050)$ \\
\hline \multirow[t]{2}{*}{ has child $<10$ years } & -0.071 & $-0.068^{\star *}$ \\
\hline & $(0.058)$ & $(0.032)$ \\
\hline \multirow[t]{2}{*}{ age } & $-0.004^{*}$ & $-0.003^{*}$ \\
\hline & $(0.003)$ & $(0.002)$ \\
\hline \multirow[t]{2}{*}{ single } & -0.029 & -0.034 \\
\hline & $(0.074)$ & $(0.051)$ \\
\hline Observations & 454 & 454 \\
\hline Zone FE & yes & yes \\
\hline Clustered s.e. & yes & yes \\
\hline Pseudo $\mathrm{R}^{2}$ & 0.17 & 0.23 \\
\hline
\end{tabular}

Notes: $* * * \mathrm{p}<0.01, * * \mathrm{p}<0.05, * \mathrm{p}<0.1$; the coefficients represent marginal effects calculated after a probit regression; standard errors are reported between brackets, and clustered at the level of the mining zone; self-reported former rebels are excluded from the sample. 


\begin{tabular}{|c|c|c|c|c|}
\hline & $\begin{array}{l}\text { Destroy } \\
\text { (1) }\end{array}$ & $\begin{array}{l}\text { Attack } \\
\text { (2) }\end{array}$ & $\begin{array}{c}\text { Fire arms } \\
\text { (3) }\end{array}$ & $\begin{array}{l}\text { Rebel } \\
\text { (4) }\end{array}$ \\
\hline \multirow[t]{2}{*}{ rebel in pit } & 0.080 & $0.097^{*}$ & $0.133^{* * *}$ & $0.140^{* * *}$ \\
\hline & $(0.063)$ & $(0.054)$ & $(0.030)$ & $(0.043)$ \\
\hline \multirow[t]{2}{*}{ witnessed killing or rape } & 0.076 & 0.062 & $0.122^{* * *}$ & $0.065^{* *}$ \\
\hline & $(0.050)$ & $(0.048)$ & $(0.040)$ & $(0.028)$ \\
\hline \multirow[t]{2}{*}{ impact Mai-Mai Shikito } & 0.046 & 0.060 & $0.130^{* * *}$ & $0.115^{*}$ \\
\hline & $(0.077)$ & $(0.059)$ & $(0.050)$ & $(0.060)$ \\
\hline \multirow[t]{2}{*}{ opinion Banro CSR } & $-0.168^{* * *}$ & $-0.109^{* *}$ & $-0.141^{* * * *}$ & $-0.166^{* * *}$ \\
\hline & $(0.061)$ & $(0.046)$ & $(0.037)$ & $(0.052)$ \\
\hline \multirow{2}{*}{ interested in working for Banro } & $-0.082^{* * *}$ & -0.102 & -0.085 & $-0.071^{*}$ \\
\hline & $(0.031)$ & $(0.067)$ & $(0.055)$ & $(0.043)$ \\
\hline \multirow[t]{2}{*}{ frequency Banro visits } & 0.009 & $0.010^{* *}$ & $0.007^{* * *}$ & $0.008^{* * *}$ \\
\hline & $(0.007)$ & $(0.004)$ & $(0.002)$ & $(0.003)$ \\
\hline \multirow[t]{2}{*}{ willingness to relocate } & 0.045 & $0.090^{*}$ & 0.030 & 0.027 \\
\hline & $(0.046)$ & $(0.054)$ & $(0.048)$ & $(0.028)$ \\
\hline \multirow{2}{*}{ willingness to reorient } & -0.001 & 0.003 & 0.001 & 0.001 \\
\hline & $(0.002)$ & $(0.003)$ & $(0.002)$ & $(0.003)$ \\
\hline \multirow[t]{2}{*}{ opinion local mediating institutions } & $-0.049^{*}$ & -0.021 & $-0.052^{* *}$ & $-0.042^{*}$ \\
\hline & $(0.028)$ & $(0.039)$ & $(0.024)$ & $(0.022)$ \\
\hline \multirow[t]{2}{*}{ opinion Banro security forces } & $0.123^{* * *}$ & $0.095^{* * *}$ & $0.064^{* * *}$ & $0.052^{* * *}$ \\
\hline & $(0.024)$ & $(0.034)$ & $(0.024)$ & $(0.019)$ \\
\hline \multirow[t]{2}{*}{ pit manager } & -0.038 & 0.002 & 0.113 & 0.032 \\
\hline & $(0.035)$ & $(0.056)$ & $(0.089)$ & $(0.051)$ \\
\hline \multirow[t]{2}{*}{ asset quintile 2} & -0.074 & -0.019 & $-0.098^{* * *}$ & -0.065 \\
\hline & $(0.083)$ & $(0.044)$ & $(0.033)$ & $(0.046)$ \\
\hline \multirow[t]{2}{*}{ asset quintile 3} & 0.035 & 0.028 & $-0.051^{*}$ & -0.010 \\
\hline & $(0.055)$ & $(0.048)$ & $(0.030)$ & $(0.028)$ \\
\hline \multirow{2}{*}{ asset quintile 4} & 0.088 & $0.104^{* *}$ & -0.036 & -0.051 \\
\hline & $(0.072)$ & $(0.045)$ & $(0.054)$ & $(0.037)$ \\
\hline \multirow[t]{2}{*}{ asset quintile 5} & 0.104 & 0.048 & -0.018 & $-0.107^{* * *}$ \\
\hline & $(0.079)$ & $(0.044)$ & $(0.032)$ & $(0.034)$ \\
\hline \multirow[t]{2}{*}{ finished high school } & $-0.111^{* *}$ & -0.029 & -0.058 & -0.037 \\
\hline & $(0.045)$ & $(0.058)$ & $(0.050)$ & $(0.053)$ \\
\hline \multirow[t]{2}{*}{ number of $\mathrm{HH}$ income sources } & $-0.073^{* *}$ & -0.041 & -0.004 & $-0.052^{* *}$ \\
\hline & $(0.034)$ & $(0.035)$ & $(0.037)$ & $(0.021)$ \\
\hline \multirow[t]{2}{*}{ born in Kamituga } & -0.040 & 0.001 & 0.042 & 0.016 \\
\hline & $(0.058)$ & $(0.043)$ & $(0.054)$ & $(0.038)$ \\
\hline \multirow[t]{2}{*}{ has child $<10$ years } & -0.056 & $-0.091^{* *}$ & -0.068 & -0.074 \\
\hline & $(0.054)$ & $(0.041)$ & $(0.068)$ & $(0.064)$ \\
\hline \multirow[t]{2}{*}{ age } & $-0.006^{* * *}$ & -0.004 & $-0.005^{* *}$ & $-0.004^{* *}$ \\
\hline & $(0.002)$ & $(0.002)$ & $(0.002)$ & $(0.002)$ \\
\hline \multirow[t]{2}{*}{ single } & -0.052 & -0.017 & -0.084 & -0.048 \\
\hline & $(0.068)$ & $(0.057)$ & $(0.088)$ & $(0.089)$ \\
\hline Observations & 469 & 469 & 469 & 469 \\
\hline Zone FE & Yes & Yes & Yes & Yes \\
\hline Clustered s.e. & Yes & Yes & Yes & Yes \\
\hline Pseudo $\mathrm{R}^{2}$ & 0.14 & 0.16 & 0.14 & 0.20 \\
\hline
\end{tabular}

Notes: $* * * \mathrm{p}<0.01, * * \mathrm{p}<0.05, * \mathrm{p}<0.1$; the coefficients represent marginal effects calculated after a probit regression; standard errors are reported between brackets, and clustered at the level of the mining zone; Destroy, Attack, Fire arms and Rebel are indicator variables that equal one for miners that display a 'probable' or 'certain' intention to destroy Banro property, attack Banro employees, use fire arms and join an armed group, respectively. 


\section{References}

Altonji, Joseph G., Todd E. Elder, and Christopher R. Taber. 2005. "Selection on Observed and Unobserved Variables: Assessing the Effectiveness of Catholic Schools." Journal of Political Economy 113 (1): 151-84.

Oster, Emily. 2019. "Unobservable Selection and Coefficient Stability: Theory and Evidence." Journal of Business \& Economic Statistics 37 (2): 187-204.

Roodman, David, Morten Ørregaard Nielsen, James G. MacKinnon, and Matthew D. Webb. 2019. "Fast and Wild: Bootstrap Inference in Stata Using Boottest." The Stata Journal 19 (1): 4-60. 